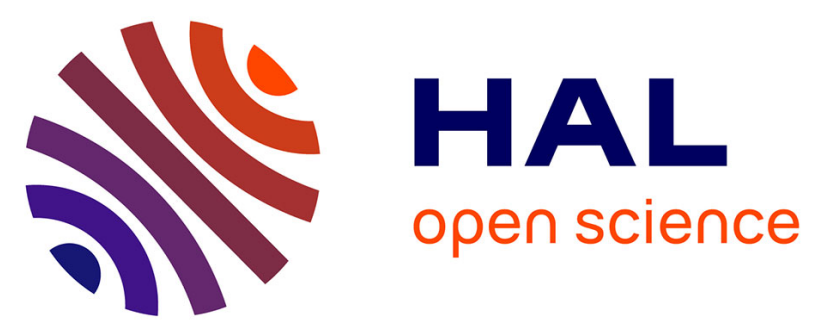

\title{
Persistent Organic Pollutants in a marine bivalve on the Marennes-Oléron Bay and the Gironde Estuary (French Atlantic coast) -Part 1: Bioaccumulation
}

\author{
Andrea Luna Acosta, Hélène Budzinski, Karine Le Menach, Hélène \\ Thomas-Guyon, Paco Bustamante
}

\section{To cite this version:}

Andrea Luna Acosta, Hélène Budzinski, Karine Le Menach, Hélène Thomas-Guyon, Paco Bustamante. Persistent Organic Pollutants in a marine bivalve on the Marennes-Oléron Bay and the Gironde Estuary (French Atlantic coast) -Part 1: Bioaccumulation. Science of the Total Environment, 2014, 514, pp.500-510. hal-01223659

\section{HAL Id: hal-01223659 \\ https://hal.science/hal-01223659}

Submitted on 3 Nov 2015

HAL is a multi-disciplinary open access archive for the deposit and dissemination of scientific research documents, whether they are published or not. The documents may come from teaching and research institutions in France or abroad, or from public or private research centers.
L'archive ouverte pluridisciplinaire HAL, est destinée au dépôt et à la diffusion de documents scientifiques de niveau recherche, publiés ou non, émanant des établissements d'enseignement et de recherche français ou étrangers, des laboratoires publics ou privés. 


\section{Persistent Organic Pollutants in a marine bivalve on the Marennes-Oléron Bay and the Gironde Estuary (French Atlantic coast) - Part 1: Bioaccumulation}

Luna-Acosta, A. ${ }^{1,4 *}$, Budzinski, H., ${ }^{2,3}$, Le Menach, K. ${ }^{2,3}$, Thomas-Guyon, H. ${ }^{1}$, Bustamante, P. ${ }^{1}$

${ }^{1}$ Littoral Environnement and Sociétés (LIENSs), UMR 7266 CNRS-Université de La Rochelle, 2 rue Olympe de Gouges - F-17042 the Rochelle Cedex 01, France

${ }^{2}$ Université Bordeaux 1, Laboratoire de Physico-ToxicoChimie de l'environnement (LPTC), UMR EPOC (UMR5805 CNRS-Université de Bordeaux 1), 351 Cours de the Libération, 33405 Talence, France

${ }^{3}$ CNRS, Laboratoire de Physico-ToxicoChimie de l'environnement (LPTC), EPOC (UMR 5805, CNRS-Université de Bordeaux 1), 351 Cours de the Libération, 33405 Talence, France

${ }^{4}$ Present address: Departamento de Ecología y Territorio, Universidad Javeriana, Transv. 4 No. $42-$ 00, Bogotá, Colombia

* Corresponding authors: A. Luna-Acosta

Departamento de Ecología y Territorio

Universidad Javeriana

Transv. 4 No. $42-00$

Bogotá, Colombia

Email: aluna1508@yahoo.com

Tel: +5713208320 Ext. 4824

Fax: +571 3208320 Ext. 4847 


\begin{abstract}
The aim of this study was to determine 1) the relevance of using the Pacific oyster Crassostrea gigas as a sentinel organism, at a juvenile stage, for polycyclic aromatic hydrocarbon (PAH) and persistent organic pollutant (polychlorobiphenyls, PCBs, polybromodimethylethers, PBDEs, and organochlorine pesticides, OCPs) contamination, 2) the potential levels of chemical organic contamination in the MarennesOleron Bay, and their potential sources 3) the potential influence of physiological or environmental factors on contaminant body burdens in oysters. To this end, juvenile oysters purchased from a oyster hatchery were transplanted to a reference site, in Bouin, and to different transplantation sites in the Marennes-Oléron Bay, the first oyster production area in France, and in the Gironde Estuary, the biggest estuary in Occidental Europe. Transplantations were done during summer and winter. Whole oyster soft tissues from each site were analyzed for PAHs, PCBs, PBDEs and OCPs. Results obtained with a transplantation period of 3 months suggest that the C. gigas, at the juvenile stage, is a relevant sentinel organism for short-term contamination for these contaminants. In addition, no significant effects of physiological factors on contaminant body burdens were observed. A principal component analysis performed with chemical body burdens allowed them to be separated into three groups: 1) the reference site, 2) Les Palles (LP) and Boyard (BOY) in winter and 3) all the other sites. The group of LP and BOY was clearly defined by the levels of PAHs and OCPs, suggesting higher levels of contamination of these chemical compounds on these sites, potentially due to local contamination sources. In addition, no relevant effects of physiological or environmental factors on contaminant body burdens were observed. Results suggest also a predominance of contaminants related to agricultural activities along the Marennes-Oléron Bay, and therefore, further studies on the presence of pesticides in this region should be considered.
\end{abstract}

Keywords: Polycyclic aromatic hydrocarbons - Persistent organic pollutants - Bivalve - Bioaccumulation Active biomonitoring 


\section{Introduction}

Polycyclic aromatic hydrocarbons (PAHs) are chemical compounds with a molecular structure containing at least two merged aromatic rings, each ring has five or six carbon atoms. Some PAHs, such as naphthalene, anthracene and fluoranthene are listed as priority pollutants by the United States Environmental Protection Agency (US EPA) and have been classified by the Water Framework Directive (WFD; Directive 2000/60/EC) as hazardous substances because they are toxic or mutagenic (genotoxic), in vertebrates and invertebrates (EC 2010).

Among other hazardous substances, a special attention has been brought to persistent organic pollutants (POPs) for several decades, because of their potential impacts on human health and the environment (El-Shahawi et al. 2010). POPs are resistant to environmental degradation, i.e. through chemical, biological, and photolytic processes. Thus, POPs have been observed to persist in the environment, be capable of long-range transport, bioaccumulate in human and animal tissue, and biomagnify in food chains. Among POPs, polychlorobiphenyls (PCBs) are a large family of organochlorine compounds of high molecular weight, extremely chemically stable, un-inflammable, and with low solubility in water. They have been widely used because of their isolating properties as dielectrics in processors and condensators, as lubricants in turbines and pumps, or as insulating fluid, among others. Another example of POPs are polybromodimethylethers (PBDEs), a group of bromated chemical products, used in certain cases as flame retardants in plastic products and textiles. Organochlorine pesticides (OCPs), such as dichlorodiphenyltrichloroethane (DDT), lindane and dieldrin, are also classified as POPs, because they are toxic, bioaccumulative, mutagenic and teratogenic.

Marennes-Oléron Bay is the first production site in France of the highly economically and ecologically important organism, the Pacific oyster Crassostrea gigas (Soletchnik et al. 1999): for a total production in France of 80600 tones year $^{-1}$ and a production value of 347 million euros in 2010-2011, the production in Marennes-Oléron Bay is of 20000 tones year ${ }^{-1}$ (FranceAgriMer 2013).

However, this area is also subjected to many recurring anthropogenic contamination by heavy metals, PAHs and POPs, influenced mainly by the Charente River, the Seudre River and the Gironde Estuary (Miramand et al. 2003, Munaron et al. 2006). In the Marennes-Oléron Bay and the Gironde Estuary, several 
studies have been carried out on heavy metal contamination (e.g. Bustamante \& Miramand, 2005, Durrieu et al. 2005, Pigeot et al. 2006), but only few studies have been done on PAHs and POPs (Miramand et al. 2003, Munaron et al. 2006, Romeo et al. 2003). Survey networks such as the chemical contamination monitoring network ROCCH (Réseau d'Observation de la Contamination Chimique du littoral, previously RNO, in France) use C. gigas as a sentinel species (Beliaeff et al. 1998). Oysters show a relatively rapid uptake and depuration and as consequence, they have a relatively short period of integration (Scanes 1997). Additionally, many studies have also been performed using caged bivalves as sentinels in active biomonitoring studies (Besse et al. 2012, Bourgeault \& Gourlay-Francé 2013, Galgani et al. 2011, Gunther et al. 1999). The main advantage in using transplanted animals over monitoring naturally settled populations is the experimental control. Experimental control is achieved using bivalves of similar genetic and environmental stocks at all test sites, pre-selecting test animal size or age group, and monitoring animals during the test. Animals can also be transplanted to areas where they might not normally be found. Serial transplants and monitoring facilitate the examination of both short- and long-term trends in contaminants distribution and related effects. Generally transplantation studies have been carried out in adult and not in juvenile organisms. However, massive summer mortalities, particularly of juveniles of $C$. gigas, have become a widespread concern in the world in recent decades (Cheney et al. 2000, Garnier et al. 2007, Perdue et al. 1981) and there is growing evidence that contaminants may be partly responsible for the observed increase in disease and mortality in $C$ gigas, by adversely affecting their immunity, and more particularly, in young life stages (Lacoste et al. 2001, Perdue et al. 1981).

In this general context, a transplantation experiment was designed in order to determine 1) the relevance of using the Pacific oyster Crassostrea gigas as a sentinel organism, at a juvenile stage, for PAH, PCB, PBDE, and OCP contamination, 2) the potential levels of chemical organic contamination in the Marennes-Oleron Bay, and their potential sources 3) the potential influence of physiological (lipid content in the digestive gland, flesh dry weight, shell dry weight and condition index) or environmental (temperature, turbidity, chlorophyll a, phytoplankton abundance and species) factors on contaminant body burdens in oysters. Thus, juvenile oysters from an oyster hatchery were transplanted to a reference site (Bouin site) for a period of 3 months and were compared to oysters transplanted to different sites in the 
Marennes-Oléron Bay and the Gironde Estuary for the same time period, i.e. 3 months, and PAH and POP body burdens, lipid content in the digestive gland, flesh dry weight and shell dry weight were determined in oyster soft tissues from the reference and transplantation sites. Studies were carried out in two different seasons, i.e. summer and winter. An additional transplantation site was added to the study (Cordouan site), since it is located in the mouth of the Gironde Estuary, the biggest estuary in Occidental Europe (Brosse 2003).

\section{Materials and methods}

\subsection{Study area and transplantation design}

At the beginning of each transplantation period, juvenile Pacific oysters $C$. gigas from same size, i.e. 3-4 $\mathrm{cm}$ in height (1 year-old), were purchased from the oyster hatchery France Naissain, located in Vendée, France. All animals were issued from the same cohort in order to reduce genotype variability, i.e. all individuals were from the same pool of spawners, with same age and genetic homogeneity. Juveniles purchased from the oyster hatchery were transplanted to Bouin (B; $46^{\circ} 58^{\prime} 28^{\prime \prime} \mathrm{N}, 2^{\circ} 00^{\prime} 02^{\prime \prime} \mathrm{W}$ ), considered as a reference site (Fig. 1a), i.e. since it is located in a zone near the oyster hatchery where oysters were purchased and because it possesses different seawater physico-chemical characteristics in comparison to the transplantation zone (Geffard et al. 2002). Juvenile oysters were also transplanted to four transplantation sites, Boyard (BOY; $45^{\circ} 58^{\prime} 0^{\prime \prime} \mathrm{N}, 1^{\circ} 15^{\prime} 0^{\prime}$ ' W), under the double influence of the Gironde and the Charente estuaries; Les Palles (LP; 45 58’ 0” N, $1^{\circ} 08^{\prime} 0$ ” W), highly influenced by the Charente River; Mus du Loup $\left(\mathrm{ML} ; 45^{\circ} 46^{\prime} 10^{\prime \prime} \mathrm{N}, 1^{\circ} 08^{\prime} 30^{\prime}\right.$ ' W), mildly influenced by the Seudre River, and Cordouan (C; 45 $35^{\prime} 11^{\prime \prime} \mathrm{N}$, $1^{\circ} 10^{\prime} 24$ ” W), highly influenced by the Gironde Estuary (Fig. 1b). A total of 100 individuals were placed in HDPE (high-density polyethylene) oyster bags, all with the same size, i.e. $1 \mathrm{~m}$ x $0.5 \mathrm{~m}$, and the same mesh size, i.e. $2 \mathrm{~cm}$. For each site, all individuals were transplanted in the same oyster bag and at the same location. These oyster bags were placed on oyster aquaculture tables, placed at a height of $40 \mathrm{~cm}$ from the substrate. Tables were all located on the same hypsometric level, in order to have an equivalent immersion time $(<15 \%$ of the time over a tidal cycle) for all the individuals that were transplanted, regardless of the geographic location (iso-altitude of about $1 \mathrm{~m}$ corresponding to low-tide water level, coefficient 90). 
Transplantation was carried out for a period of three months (i.e. 90 days for each transplantation period and for each site), from April to June 2008 and from October to December 2008. Three months after transplantation, 5 oysters from each site were collected for chemical analyses in summer (June 2008) and winter (December 2008) and were processed immediately after their arrival in the laboratory. Back to the laboratory, soft tissues were removed from the shells, homogenized using an Ultra Turrax (T25 basic, IKAWERKE) and a Thomas-Potter homogenizer (IKA-Labortechnik RW 20.n, size 0.13-0.18 mm), freeze-dried and weighted (dry weight; $\mathrm{dw}$ ) for condition index analyses, and then pooled and frozen $\left(-80^{\circ} \mathrm{C}\right)$ for chemical analyses.

\subsection{Chemical analyses}

Chemical analyses were carried out in one pool of 5 oysters per site and per season. Each pool was analysed in triplicate for all the analyses. Freeze-dried oysters $(0.5 \mathrm{~g})$ were extracted by Accelerated Solvent Extraction (ASE) system with dichloromethane (adapted from Tapie et al. 2008). The internal standards were gravimetrically added prior to the extraction and one extraction blank was performed with each series of extraction.

For PAH analysis (Baumard et al. 1999), the ASE extract (same parameters as above without acidic silica gel) was directly preconcentrated using a Vacuum Evaporation System (Rapidvap Labconco, Kansas city, MO, USA). A purification step on alumina and silica micro-columns was performed. The extract was passed through the alumina column and PAHs were further eluted with dichloromethane. The sample was then loaded onto the silica column. The aliphatic fraction eluted with pentane was discarded and PAHs were then eluted with a mixture of pentane/dichloromethane $(65 / 35, \mathrm{v} / \mathrm{v})$. The final extract was preconcentrated in isooctane and analysed by gas chromatography/mass spectrometry (GC-MS). Perdeuterated phenanthrene, fluoranthene, chrysene benzo[e]pyrene, benzo[a]pyrene and benzo[ghi]perylene were used as internal standards.

In order to determine PCB, PBDE and OCP concentration in oyster tissues, an extraction-purification performed by the ASE 200 System (Dionex, Voisins le Bretonneux, France) coupled with purification on an acid silica gel column was applied (Tapie et al. 2008). Extraction cells of $22 \mathrm{ml}$ were used. Then, acidic 
silica gel $(5 \mathrm{~g})$ was added to the extraction cell and then the sample $(0.5 \mathrm{~g})$ was introduced, and mixed with glass pearls. The parameters used during the extraction procedure were as follows: temperature $\left(100^{\circ} \mathrm{C}\right)$, static time ( $8 \mathrm{~min})$, solvent (dichloromethane), pressure (130 bars), heating time (5 min), flush volume (60 $\%)$, and purge time $(60 \mathrm{~s})$. The final extract was preconcentrated in isooctane and analysed by gas chromatography coupled to electron capture detector (GC-ECD). DDTd8, and PCB congeners 30, 103, 155, and 198 were used as internal standards.

Polyaromatic hydrocarbons (PAHs) were measured using a gas chromatograph (HP 6890. Agilent technologies, Palo Alto, CA, USA) equipped with a splitless injector and coupled to a MSD 5975 mass spectrometer (Baumard et al. 1999). A total of 29 PAH compounds were analysed (Table 1). Organohalogenated compounds, i.e. polychlorobiphenyls (PCBs), polybromodimethylethers (PBDEs) and organochlorine pesticides (OCPs), were quantified using a gas chromatograph (HP 6890 Hewlett Packard, Palo Alto, Ca, USA) equipped with a splitless injector and coupled to an electron capture detector (Thompson \& Budzinski 2000; Tapie et al. 2008) and confirmed using a gas chromatograph (Agilent Technologies 7890A) coupled to MS/MS (Agilent technologies 7000).

A total of 10 PCB congeners, 4 PBDE and 13 OCP congeners were analysed (Tables 2 and 3). Concentrations of organic contaminants are expressed in $\mu \mathrm{g} \mathrm{kg}^{-1}$ flesh dry weight (dw).

\subsection{Quality control}

To ensure quality assurance, procedural blanks were regularly performed during the extraction process (representing less than $10 \%$ of the sample content) and all the results presented are corrected by taking into account blank levels. Recoveries of internal standards were greater than $70 \%$ in all cases with an average of $90 \%$. The validity of this method for PAH, PCB, PBDE and OCP analyses was confirmed by the extraction and analysis of a certified matrix SRM 2977 (mussel tissues, Perna perna, from Guanabara Bay, Brazil) provided by the NIST (Gaithersburg, MD, USA). The recoveries for five replicates on this SRM were between $72 \%$ and $116 \%$ with reproducibility ranging from $7 \%$ to $17 \%$ depending on the compounds. Syringe standards (pyrene d10, octachloronaphthalene) were added just before the injection to control recoveries of internal standards used for quantification. Purity of standards varied between $98.7 \%$ and $100 \%$ and were 
purchased at LGC standard (Molsheim, France) for PCB, OCP, PBDE119 and PBDE99 standards, at Interchim (Montluçon, France) for PBDE47 and PBDE153 standards, and at Cluzeau Info Labo (Sainte Foy La Grande, France) for 4,4' DDT standard. Limits of quantifications were comprised between 0.3 and $0.6 \mu \mathrm{g}$ $\mathrm{kg}^{-1} \mathrm{dw}$ depending on the compounds (limits of detection were comprised between 0.1 and $0.2 \mu \mathrm{g} \mathrm{kg}^{-1} \mathrm{dw}$ ).

\subsection{Lipids in the digestive gland and condition index}

Lipids were quantified in three pools of digestive gland from three oysters each, per site and per season. Methodology for obtaining data for this parameter is described in Luna-Acosta et al., submitted for this volume.

Condition index in juvenile oysters was calculated by the method of Lobel and Wright (1982), and expressed in mg flesh dry weight $\mathrm{g}^{-1}$ shell dry weight.

It is important to note that these parameters have been presented, analysed and discussed in LunaAcosta et al., submitted for this volume, and therefore, results of these parameters will only be presented in the discussion section of this manuscript.

\subsection{Statistical analysis}

All values are reported as mean \pm standard deviation $(\mathrm{SD})$. Statistical analysis was carried out with STATISTICA 7.0. Values were tested for normality (Shapiro test) and homogeneity of variances (Bartlett test). In some cases, logarithmic transformations $\left(\log _{10}\right)$ were used to meet the underlying assumptions of normality and homogeneity of variances. Two-way MANCOVAs (covariate: shell dry weight, flesh dry weight or condition index) were used to compare oyster contaminant contents between different seasons, with site and season as fixed factors (Zar 1984). Statistical significance was designed as being at the level of $\mathrm{p}<0.05$. Since no effects were observed by the tested covariates ( $p>0.05)$, a two-way MANOVA was used to test significant differences of contaminants between sites and seasons, with site and season as fixed factors (Zar 1984). When the null hypothesis ( $\mathrm{H}_{0}$ : no difference between sites or within sites at different seasons) was rejected, significant differences were tested using Tukey's HSD test. Then, we analyzed the relationships 
between contaminants (PAHs, PCBs, PBDEs, OCPs) using a principal component analysis (PCA). The PCA was based on the correlation matrix and normalised data for each variable (i.e. centred and divided by the standard deviation).

\section{Results and discussion}

Tables 1, 2 and 3 show mean levels ( \pm SD, in $\mu \mathrm{g} \mathrm{kg}^{-1}$ dry weight) of PAHs, PCBs, PBDEs and OCPs in oyster soft tissues. Over the different sampling stations (i.e. reference and transplantation sites) and seasons (i.e. summer and winter), these levels ranged between $81 \pm 11$ and $236 \pm 43 \mu \mathrm{g} \mathrm{kg}^{-1} \mathrm{dw}$ for PAHs, $15 \pm 1$ and $89 \pm 39 \mu \mathrm{g} \mathrm{kg}^{-1} \mathrm{dw}$ for PCBs, $0.4 \pm 0.3$ and $2.9 \pm 0.7 \mu \mathrm{g} \mathrm{kg}^{-1} \mathrm{dw}$ for PBDEs, $3 \pm 0$ and $19 \pm 1 \mu \mathrm{g} \mathrm{kg}^{-1} \mathrm{dw}_{\text {for }}$ OCPs (Tables 1-3). Results on lipids in the digestive gland, flesh $\mathrm{dw}$, shell $\mathrm{dw}$ and condition index are presented in Table 4. Two-way MANCOVAs revealed no significant effect of lipids in the digestive gland $\left(F_{(4,16)}=1.02, p=0.43\right)$, flesh dw $\left(F_{(4,16)}=0.62, p=0.65\right)$, shell dw $\left(F_{(4,16)}=1.56, p=0.23\right)$ or condition index $\left(F_{(4,16)}=0.54, p=0.71\right)$, on contaminant body burden in oysters. Since no effects were observed by the tested covariates ( $p>0.05)$, a two-way MANOVA was used to test significant differences of contaminants between sites and seasons, with site and season as fixed factors, and results revealed a significant effect of site and season $\left(F_{(16,53)}=6.8, p<0.001\right)$. Since the null hypothesis $\left(\mathrm{H}_{0}\right.$ : no difference between sites or within sites at different seasons) was rejected, significant differences were tested using Tukey's HSD test for each contaminant and results are presented in Tables 1,2 and 3.

\subsection{PAHs}

Values of PAH body burden of the present study, varied from $80 \pm 32$ to $236 \pm 43 \mu \mathrm{g} \mathrm{kg}^{-1} \mathrm{dw}$ (Table 1), and are in the range of previous transplantation studies with caged mussels (Mytilus galloprovincialis) in the Mediterranean Sea for 12 weeks (i.e. 3 months), at 123 stations along the Mediterranean coasts of Spain, France, Italy, North Tunisia, Algeria and Morocco (range of 22 to $106 \mu \mathrm{g} \mathrm{kg}^{-1} \mathrm{dw}$; Galgani et al. 2011), and in sites close to sites of the present study, i.e. Fier d'Ars, Baie d'Aguillon and La Rochelle, for transplantation periods of 1 month (range of 105 to $420 \mu \mathrm{g} \mathrm{kg}^{-1} \mathrm{dw}$; Romeo et al. 2003). In summer, PAH 
levels were $\sim 2.5$-fold significantly ( $\mathrm{p}<0.05$ ) higher in oysters from LP (LPs) than in oysters from ML (MLs) and $\mathrm{C}(\mathrm{Cs})$ but no significant differences were found with the reference site (Bs; Table 1). In winter, PAH levels in oysters from BOY (BOYw) were $\sim 1.5$-fold significantly $(\mathrm{p}<0.05)$ higher than in oysters from $\mathrm{B}$ (Bw) and PAH levels in oysters from BOY (BOYw), LP (LPw) and ML (MLw) were $~ 1.5$ to 2-fold significantly $(\mathrm{p}<0.05)$ higher than in oysters from $\mathrm{C}(\mathrm{Cw}$; Table 1$)$. Moreover, significant differences $(\mathrm{p}<0.05)$ of $\Sigma \mathrm{PAH}$ body burdens were found between BOYs in summer (BOYs) and BOYw and between MLs and MLw, with maximal levels in winter and minimal levels in summer. These results are in agreement with in situ studies carried out with oysters and mussels in the Bay of Biscay, on the Atlantic coast (Orbea et al. 2002), and in the northwest coast of the Mediterranean Sea (Bodin et al. 2004), in which PAH levels were higher in winter than in summer. In addition, PAH levels increased significantly only in BOYw and MLw, suggesting a specific PAH contamination source in the south of Marennes-Oléron Bay (i.e. ML) and at proximity of Marennes-Oléron islands (i.e. BOY) in winter. This also suggests that, in these sites in summer, PAHs are either rapidly depurated and/or metabolised and that this could be related to seawater temperatures above $19^{\circ} \mathrm{C}$ in summer (Bustamante et al. 2011; Table 1).

Phenanthrene, fluorene, triphenylene+chrysene, benzo(b,k,j)fluoranthene and $\mathrm{C}_{2}$-napthalene accounted among the most accumulated PAHs in oyster tissues: in B, the most accumulated PAHs were phenanthrene and benzo(b,k,j)fluoranthene (12-15\%), in BOY, phenanthrene (9-11\%), benzo(b,k,j)fluoranthene (8-16\%) and fluorene $(9-14 \%)$, in LP, benzo(b,k,j)fluoranthene (10-12\%) and fluorene (17-19\%), in ML, benzo(b,k,j)fluoranthene (18-20\%), in C, benzo(b,k,j)fluoranthene (9-11\%) and fluorene (8-14\%; Table 1). In all sites and seasons, parent PAHs were more present than alkylated PAHs with a percentage of $70-90 \%$ of total PAHs. Heavy PAHs (containing more than 3 aromatic rings) represented $60-80 \%$ of total PAHs, except for B and C in summer were they accounted for $46 \%$ of total PAHs (Table 1). Heavy PAHs, which are more hydrophobic than light PAHs, were more accumulated in oysters than the latter. This result is in agreement with Gunther et al. (1999) and Orbea et al. (2002), who reported a strong ability of oysters and mussels to accumulate high molecular weight PAHs. This result is also in agreement with Baumard et al. (1999), who reported that bivalves collected in the Altantic coast, considered as a turbid area, are likely to be exposed mainly to particulate contamination, and therefore to accumulate higher molecular weight compounds in a greater extent than the lower molecular weight 
compounds, in comparison to bivalves sampled in clear waters (low turbidity) of the Mediterranean, where bivalves are mainly exposed to the dissolved fraction of contamination.

In addition, phenanthrene/anthracene, fluoranthene/pyrene and methyl phenanthrene/phenanthrene ratios indicated that PAHs levels in the present study were mostly of pyrolytic origin, i.e. by the incomplete combustion of organic matter (Readman et al. 2002), except for Bs, BOYs and winter and Cw, where results of the phenanthrene/anthracene ratio suggest a potential petrogenic source, i.e. as a result of spillage oil of diesel and/or fuel oil (Readman et al. 2002; Fig. 3).

PAH body burdens of the present study were compared to data collected by the national monitoring program ROCCH, from 2003 to 2007 at, or at proximity of, the sites chosen in the present study (Table 5). Fluoranthene levels in the present study were lower to previous values reported in ML, BOY and LP by ROCCH (Table 5). This could be due to the fact that ROCCH collects adult oysters, while the present study was based on juvenile oysters. Young organisms are known to have an increased metabolic rate, which may affect chemical uptake and distribution rates (Black et al. 1997), with probable higher accumulation and/or depuration rates of some chemical compounds, according to their properties. It is important to notice also that oysters in the present study were only present in the reference and transplantation sites for a period of 3 months, contrary to oysters collected by ROCCH, i.e. not transplanted but found in situ. Nevertheless, it is interesting to notice that levels equivalent to the ones reported by ROCCH were detected in LPs and in BOYw in the present study, suggesting local sources of PAHs.

Moreover, results of the present study, revealed relatively low PAH levels, even if they were above $50 \mu \mathrm{gg}^{-1} \mathrm{dw}$, which is considered as the limit for background pollution (Ruiz et al. 2011), except for BOYw, LPw and MLw, where PAH body burden were equal to or above $200 \mu \mathrm{g} \mathrm{kg}{ }^{-1}$ dw (i.e. $236 \pm 43,205 \pm 9$ and $200 \pm 40 \mu \mathrm{g} \mathrm{kg}^{-1} \mathrm{dw}$ for BOYw, LPw and MLw, respectively), which suggests the vicinity of urban or industrial hydrocarbon sources in these sites, in winter (Ruiz et al. 2011).

\subsection{PCBs}

In summer and winter, significant $(\mathrm{p}<0.05)$ differences were observed between the reference $(\mathrm{B})$ and the transplantation sites, with PCB levels in oysters from the former being $\sim 2-5$-fold significantly $(\mathrm{p}<0.05)$ 
higher than in oysters from LP, ML and C (Table 2). Oysters accumulated mainly penta- (18 to $40 \%$ ) and hexachlorobiphenyls (30 to 70\%) and the hexachlorobiphenyl congener $\mathrm{PCB}_{153}$ was the most accumulated PCB, accounting for 30 to $50 \%$ of total PCBs (Table 2). These results are in agreement with previous studies on oysters and mussels (Porte \& Albaiges 1993; Orbea et al. 2002).

B was considered as a reference site in previous studies carried out with heavy metals (Geffard et al. 2002). However, results of the present study reveal that B should no longer be considered as a reference site and show that special care must be taken when selecting a reference site. For monitoring it is essential that the reference population for transplantation is considered carefully since it should not be considered as a reference site for a certain type of contaminants, e.g. metals but no others, e.g. organic contaminants. In previous studies, it has been noted the difficulty to establish a reference site that is not polluted (Davies \& Vethaak 2012). In addition, control seawater may not be appropriate as a reference because it lacks the physico-chemical and microbiological properties of an elutriate, some of which may affect the response (Davies \& Vethaak 2012) Davies, I. M. and Vethaak, A. D. 2012). Integrated marine environmental monitoring of chemicals and their effects. ICES Cooperative Research Report No. 315.277 pp.). On the top of that, other parameters, such as natural marine upwelling, may also affect contamination levels in a reference site (Greenfield et al. 2014).

Nevertheless, B possesses different seawater physico-chemical characteristics and river inputs in comparison to the transplantation zone, and therefore information on bioaccumulation and depuration processes of chemical contaminants in oysters can be evaluated. Results on PCB levels suggest also that oysters are able to depurate important quantities of PCB if they are transferred to sites possessing low levels of PCB, and this, independently of the season. Additionally, lower levels of PCBs were reported in the present study in comparison to data collected by $\mathrm{ROCCH}$, especially in $\mathrm{C}$ (Table 6). This result suggests that pollution sources of PCB in C diminished in 2008 and/or that lower levels were due to a lower time of exposure in the present study, i.e. 3 months. PCB levels varied from 71 to $303 \mu \mathrm{g} \mathrm{kg}^{-1} \mathrm{dw}$ in a transplantation study for periods of 1 month with $M$. galloprovincialis in sites close to sites of the present study (Romeo et al. 2003). These values were higher than levels from the present study which varied from $15 \pm 1$ to $89 \pm 39 \mu \mathrm{g} \mathrm{kg}^{-1} \mathrm{dw}$, which is in agreement with the hypothesis of a decrease of PCB levels in recent years. 


\subsection{PBDEs}

Concerning PBDEs, levels were low in all sites, no significant differences were observed in summer between the sites (Table 2$)$, and only a significant $(\mathrm{p}<0.05)$ increase was observed in winter in $B$, in comparison to summer, suggesting a potential income of PBDEs from the Loire river. Moreover, mean body burdens of the sum of PBDEs ranged between 0.4 and $2.9 \mu \mathrm{g} \mathrm{kg}^{-1} \mathrm{dw}$, with PBDE$_{47}$ and PBDE$_{99}$ body burdens ranging between 0.4 to 1.5 and between 0.2 and $1.5 \mu \mathrm{g} \mathrm{kg}^{-1} \mathrm{dw}$, respectively. These values are in the range of results of a previous study, in which the mean body burden of the sum of 13 PBDEs $\left(\Sigma_{13}\right.$ PBDEs, instead of 4 PBDEs in the present study) in mussels collected from Normandy, on the French Atlantic coast, and from Thau Lagoon, on the French Mediterranean coast, were equal to 0.4 and $0.9 \mu \mathrm{g} \mathrm{kg}^{-1} \mathrm{dw}$, respectively (Bodin et al. 2007, Hong et al. 2009), and were lower than values obtained in Masan Bay (South Korea), a site presenting a growing pollution problem, i.e. $13 \mu \mathrm{g} \mathrm{kg}^{-1} \mathrm{dw}$ (Hong et al. 2009). However, these studies were carried out in mussels collected directly on the site and to our knowledge, no previous transplantation studies have been carried out in oysters to evaluate PBDE body burdens, and therefore, further comparisons with our findings were not possible.

\subsection{OCPs}

In summer, OCP levels in oysters from B and BOY were $\sim 3$-fold significantly $(\mathrm{p}<0.05)$ higher than in oysters from ML and C (Table 3). In winter, OCP levels were $~ 2$-fold significantly $(\mathrm{p}<0.05$ ) higher in oysters from BOY than in oysters from B. Moreover, OCP levels in oysters from BOY were 2-fold significantly $(\mathrm{p}<0.05)$ higher than in oysters from LP and C. The most accumulated OCP compounds were lindane and DDT metabolites: $\sim 21 \%$ of lindane and $\sim 22 \%$ of 2,4 '-DDE of total OCPs in B samples, $\sim 26 \%$ of 2,4'-DDE and $33 \%$ of 4,4'DDE+dieldrin in BOY samples, 28,26 and $33 \%$ of 4,4'DDE+dieldrin in LP, ML and C samples, respectively, and 23, 34 and $30 \%$ of 4,4'-DDD in LP, ML and C samples, respectively (Table $3)$.

In France, it is forbidden to sell and use DDT and lindane since 1972 and 1998, respectively. However, DDT metabolites and lindane were the most accumulated OCPs in the present study. Interestingly, 
DDT (and metabolites) levels were higher in BOY and LP in the present study than levels collected by $\mathrm{ROCCH}$, especially in winter, and lindane levels were higher in the reference site and in LP in winter than levels collected by ROCCH (Table 6). These results suggest local pollution sources of pesticides, especially in BOY and LP.

The organochlorine compound $\mathrm{pp}^{\prime}$-dichlorodiphenylethylene ( $\mathrm{pp}^{\prime}$-DDE) is a degradation product of $\mathrm{pp}^{\prime}$-dichlorodiphenyltrichloroethane ( $\mathrm{pp}^{\prime}$-DDT). Since DDT is an hydrophobic compound, it persists in the environment, especially in soils in areas treated with DDT in the past. DDT is also volatile and can be evaporated and transported away from application sites as a gas (Sanchez et al. 1993). The DDT degradation is slow and consequently it is conditioned by different variables. DDE can be formed from DDT, for example, either by UV-irradiation in the atmosphere or by metabolisation by micro-organisms under aerobic conditions, which may lead to high levels of accumulation in abiotic and biotic matter (Brown et al. 1986). Indeed, DDE is even more persistent in the environment and at least as toxic as DDT (Sanchez et al. 1993). Neither DDT nor DDE dissolves well in water, and they combine quite strongly with soil particles. As a result these compounds concentrate in sediments and can be transported from application sites as dust and eroded sediment carried by water. The highest concentrations of $\mathrm{pp}^{\prime}$-DDE were found in oysters transplanted to BOY, during winter $\left(12 \mu \mathrm{g} \mathrm{kg}{ }^{-1} \mathrm{dw}\right)$. Like the concentrations of PAHs and PCBs, those of $\mathrm{pp}^{\prime}-\mathrm{DDE}$ in the soft tissue of oysters $C$. gigas confirm the influence of local pollution sources on the distribution of pp'-DDE in the Marennes-Oléron Bay.

It seems also that the high concentration of DDE in oysters from BOY in winter could be due to high oxygen content in the ambient water, which promotes the conversion of DDT to DDE. Elevated contents of DDT and metabolites in BOY and LP, in comparison to other sites, also suggest that the presence of these contaminants in these zones could be related to the influence of the Charente River.

In the present study, values of the PCBs/pp'-DDE and PAHs/pp'-DDE ratios ranged from 4 to 24 (Fig. 4a) and to 19 to 216 (Fig. 4b), respectively. There is only one study to our knowledge in which PCBs/pp'-DDE and PAHs/pp'-DDE ratios have been calculated in bivalves (Potrykus et al. 2003). For this study, contents and patterns of selected organic pollutants (PAHs, PCBs and DDTs) were assessed in the southern part of the Baltic Sea, using blue mussels, $M$. trossulus, as sentinel organisms. In the present study, PCBs/pp'-DDE ratio ranged from 2 to 5 and PAHs/pp'-DDE ratio ranged from 2 to 10, and it was concluded that the higher 
PCBs/pp'-DDE and PAHs/pp'DDE ratios in contaminated versus reference sites, reflect the predominance of industrial over agricultural activities in these contaminated sites (Potrykus et al. 2003). Contrary to this study, the PCBs/pp'-DDE ratio in oysters transplanted in the Marennes-Oléron Bay and the Gironde Estuary in the present study, is two to four times lower than the PCBs/pp'-DDE ratio in oysters from the reference point (B). These results suggest a predominance of agricultural over industrial activities, as potential sources of contamination in Marennes-Oléron Bay and Gironde Estuary sites, except for ML in winter.

\subsection{Correlations between contaminant contents}

The first two principal components had eigenvalues $>1$ and accounted for $82 \%$ of the total variation present in the data set (46\% and 36\% for axis 1 and 2, respectively). PAH and OCP values were the variables more contributing to the first axis, whereas PCB and PBDE were the variables more contributing to the second one (i.e. contribution of the variable $\geq 25 \%$, Fig. 2). Principal component 1 indicated that increased PAH concentrations were associated with increased OCP concentrations (Fig. 2). Principal component 2 showed that increased PCB concentrations were associated with increased PBDE concentrations (Fig. 2). Similar correlations observed between PAH and OCP, and between PCB and PBDE levels, suggest similar contamination sources of these two types of contaminants, respectively. Site sample analysis (Fig. 2) shows three well-defined groups, depending on levels of contaminants: 1) the first group, with Bs and Bw, corresponding to the reference site in summer and winter respectively, is clearly defined by the levels of PCBs and PBDEs 2) the second group, with Les Palles in winter (LPw) and Boyard in winter (BOYw) is clearly defined by the levels of PAHs and OCPs, and 3) the third group encompasses all the other sites. These results suggest that, in terms of PAH and OCP contents in oyster tissues, the sites of Boyard and Les Palles in Marennes-Oléron Bay are likely to be the most contaminated of all the studied sites.

In addition, although the total content of lipids in oysters was not determined in this study, we have taken into consideration two important physiological parameters characterising the bivalves exposed to organic contaminants: lipid levels in the digestive gland and the condition index (expressed in mg flesh dry weight $\mathrm{g}^{-1}$ shell dry weight; Table 4). Two-way MANCOVA analyses were carried out to test if these parameters affect contaminant body burdens and no significant differences $(p>0.05)$ were observed, i.e. the 
lipid content in the digestive gland, the size and/or the gross body state of oysters had no significant effect on PAH, PCB, PBDE or OCP body burdens. These results are in agreement with previous studies that have suggested that neither PAH, PCB, nor DDT contamination levels are affected by the condition index and/or the $\%$ content of lipids, concerning the bivalves (Galgani et al. 2011; Thompson et al. 1999).

Moreover, based on environmental data collected from French monitoring networks, differences in temperature, turbidity, chlorophyll a, phytoplankton abundance and species were observed for all sites between summer and winter (Table 4). Independently of the site, temperature, phytoplankton concentration and chlorophyll a levels were lower, in winter in comparison to summer, while turbidity levels were higher. Thus, environmental factors could explain, in part, differences observed in the present study in levels of PAHs, PCBs and PBDEs between summer and winter. A slight increase of the temperature was observed in a North-South gradient in summer, with higher values observed in C. However, no increase or decrease of contaminant contents was observed in a North-South gradient. Therefore, these data suggest that environmental parameters are not the main cause of differences in contaminant content in oysters' flesh between sites, and are in agreement with the hypothesis of local inputs, as major sources of contamination observed in the present transplantation study.

\section{Conclusion}

In the present study, a transplantation experiment was designed in order to determine the relevance of using juvenile Pacific oysters Crassostrea gigas as a sentinel organisms for chemical organic contaminants, the potential levels of chemical organic contamination in the Marennes-Oléron Bay and their potential sources and the potential effects of physiological or environmental factors on contaminant body burdens in oysters. Results obtained with a transplantation period of 3 months suggest that the $C$. gigas, at the juvenile stage, is a relevant sentinel organism for short-term contamination for PAHs, PCBs, PBDEs and OCPs. Additionally, an important difference in the distribution of contaminants in B and C in comparison to BOY, ML and LP, which is not likely to be influenced by the physiological (i.e. lipid content in the digestive gland, flesh dry weight, shell dry weight and condition index) or environmental factors (i.e. temperature, turbidity, 
chlorophyll a, phytoplankton abundance and species) measured and collected by French monitoring networks, respectively, suggest different sources of pollution, depending on the season.

It could be interesting to carry out transplantation experiments with oysters at different depths from the surface, in order to evaluate the vertical distribution of contaminants and potential pollution sources (e.g. sediments or outfall; e.g. Salazar \& Salazar 1995). In order to avoid some difficulties encountered in the present study, it could be also interesting to analyze inorganic and organic contaminant body burdens in bivalves from different potential reference sites on the French Atlantic coast, at different seasons, and determine which sites could be used as reference sites for this type of studies. If bivalves for transplantation studies are bought in a hatchery, it should not be assumed that, since they would be sold for human consumption they should be free or have very low levels of contaminants, and therefore, it could be also interesting to evaluate contaminant contents of these bivalves prior to the transplantation study.

Additionally, the potential predominance of agricultural over industrial activities as contamination sources along the Marennes-Oléron Bay, except for ML in winter, suggests that further studies on the presence of pesticides in this region should be considered, especially in winter and in zones influenced by the Charente River.

\section{Acknowledgments}

This study was supported by a $\mathrm{PhD}$ grant from the Conseil Général de the Charente-Maritime for A. LunaAcosta. Authors wish to thank M. Baudrimont and D. Fichet for supporting this study through the 'Défi Cadmium' project, financed by Région Poitou-Charentes, Région Aquitaine, Conseil Général de la Charente-Maritime, Conseil Général de la Gironde, and Agence de l'Eau Adour-Garonne. CPER A2E is also acknowledged for financial support. Authors acknowledge also R. Galois for his scientific advice for lipid and glycogen content analyses, C. Trichet, D. Vilday, M. Caille, J. Laheux and M. Pelmoine for their assistance during the study, and the Ifremer networks ROCCH and RAZLEC, the 'Site Ifremer consacre à l'environnement littoral' and especially O. Le Moine, P. Soletchnik, S. Guesdon, P-G. Sauriau, P. Miramand and T. Guyot, for data and references from Marennes-Oléron Bay. Authors wish to warmly thank also T. Caquet for his scientific advice and help in statistical analyses. 


\section{References}

Baumard P, Budzinski H, Garrigues P, Dizer H, Hansen PD. Polycyclic aromatic hydrocarbons in recent sediments and mussels (Mytilus edulis) from the Western Baltic Sea: occurrence, bioavailability and seasonal variations. Mar Environ Res 1999; 47:17-47.

Beliaeff B, O'Connor TP, Claisse D. Comparison of chemical concentrations in mussels and oysters from the United States and France. Environ Monit Assess 1998; 49:87-95.

Besse JP, Geffard O, Coquery M. Relevance and applicability of active biomonitoring in continental waters under the Water Framework Directive 2012; 36 :113-27.

Black MC, Westerfield SM, Belin JI, Van Vreede KB. Biomarker assessment of environmental contamination: In-situ studies with freshwater bivalves. Proceedings of the 1997 Georgia Water Resources Conference, March 20-22, 1997, Athens, Georgia.

Bourgeault A, Gourlay-Francé C. Monitoring PAH contamination in water: Comparison of biological and physico-chemical tools 2013; 454-4555:328-36.

Bodin N, Burgeot T, Stanisiere JY, Bocquene G, Menard D, Minier C, Boutet I, Amat A, Cherel Y, Budzinski H. Seasonal variations of a battery of biomarkers and physiological indices for the mussel Mytilus galloprovincialis transplant into the northwest Mediterranean Sea. Comp Biochem Physiol 2004; 138C:411-27.

Brosse L. Caractérisation des habitats des juvéniles d'esturgeon européen, Acipenser sturio, dans l'estuaire de la Gironde: Relations trophiques, hiérarchisation et vulnérabilité des habitats. Université de Toulouse III; 2003.

Brown D, Gossett RW, Mchugh SR. Oxygenated metabolites of DDT and PCB in marine sediments and organisms. In: Capuzzo JM, Kester DR, editors. Biological processes and waters in the oceans: Oceanic processes in marine pollution. Florida: Krieger, Malabar, 1986; p.61-9.

Bustamante P, Miramand P. Subcellular and body distributions of 17 trace elements in the variegated scallop Chlamys varia from the French coast of the Bay of Biscay. Sci Total Environ 2005; 337:59-73.

Bustamante P, Luna-Acosta A, Clemens S, Cassi R, Thomas-Guyon H, Warnau M. Bioaccumulation and metabolism of ${ }^{14} \mathrm{C}$-pyrene by the Pacific oyster Crassostrea gigas exposed via seawater. Chemosphere 2012; 87:944-50.

Cheney D, MacDonald B, Elston R. Summer mortality of Pacific oysters, Crassostrea gigas (Thunberg): initial findings on multiple environmental stressors in Puget Sound, Washington. J Shellfish Res 2000; 19:353-9.

Davies I, Vethaak A. Integrated marine environmental monitoring of chemicals and their effects. ICES Cooperative Research Report No. 315, 2012..

Durrieu G, Maury-Brachet R, Girardin M, Rochard E, Boudou A. Contamination by heavy metals (Cd, Zn, $\mathrm{Cu}$ and $\mathrm{Hg}$ ) of eight fish species in the Gironde estuary (France). Estuaries Coasts. 2005; 28:581-91. 
EC (European Commission). Guidance on surface water chemical monitoring under the Water Framework Directive. Guidance document no 25. Technical report 210.3991. Common implementation strategy for the framework directive, EC, Brussels, Belgium, 2010.

El-Shahawi MS, Hamza A, Bashammakh AS, Al-Saggaf WT. An overview on the accumulation, distribution, transformations, toxicity and analytical methods for the monitoring of persistent organic pollutants. Talanta 2010; 80:1587-97.

FranceAgriMer. The fisheries and aquaculture sector in France. Montreuil-sous-Bois. FranceAgriMer Office of Communication and Information, 2013.

Galgani F, Martinez-Gomez C, Giovanardi F, Romanelli G, Caixach J, Cento A, Scarpato A, BenBrahim S, Messaoudi S, Deudero S, Boulahdid M, Benedicto J, Andral B. Assessment of polycyclic aromatic hydrocarbon concentrations in mussels (Mytilus galloprovincialis) from the Western basin of the Mediterranean Sea, Environ Monit Assess 2011; 172: 301-17.

Garnier M, Labreuche Y, Garcia C, Robert M, Nicolas JL. Evidence for the involvement of pathogenic bacteria in summer mortalities of the Pacific oyster Crassostrea gigas. Microb Ecol 2007; 53:187-96.

Geffard A, Amiard J, Amiard-Triquet C. Kinetics of metal elimination in oysters from a contaminated estuary. Comp Biochem Physiol 2002; 131C:281-93.

Granby K, Spliid H. Hydrocarbons and organochlorines in common mussels from the Kattegar and the belts and their relation to condition indices. Mar Poll Bull 1995; 30:74-82.

Greenfield R, Brink K, Degger N, Wepener V. The usefulness of transplantation studies in monitoring of metals in the marine environment: South-African experience. Mar Poll Bull 2014; In Press.

Gunther AJ, Davis JA, Hardin DD, Gold J, Bell D, Crick JR, Scelfo GM, Sericano J, Stephenson M. Longterm bioaccumulation monitoring with transplanted bivalves in the San Francisco estuary. Mar Poll Bull 1999; 38:170-81.

Lacoste A, Jalabert F, Malham SK, Cueff A, Poulet SA. Stress and stress-induced neuroendocrine changes increase the susceptibility of juvenile oysters (Crassostrea gigas) to Vibrio splendidus. Gen Comp Endocrinol 2001: 67:2304-9.

Lobel P, Wright D. Relationship between body zinc concentration and allometric growth measurements in the mussel Mytilus edulis. Mar Biol 1982; 66:145-50.

Miramand P, Guyot T, Pigeot J Sources et impacts potentiels des micropolluants chimiques sur un écosystème littoral exploité: L'exemple des côtes de Charente-Maritime. J Phy IV (Proceedings) 2003; 108:3-6.

Munaron D, Dubernet J, Delmas F, Stanisiere J, Scribe P. Assessment of the quantities of herbicides and nutrients brought down by the river Charente to the coast and modelling of the dispersion of atrazine in the Marennes-Oléron bay. Cah Biol Mar 2006; 47:85-92. 
Orbea A, Ortiz-Zarragoitia M, Sole M, Porte C, Cajaraville MP. Antioxidant enzymes and peroxisome proliferation in relation to contaminant body burdens of PAHs and PCBs in bivalve molluscs, crabs and fish from the Urdaibai and Plentzia estuaries (Bay of Biscay). Aquatic Toxicol 2002; 58:75-98.

Perdue J, Beattie J, Chew K. Some relationships between gametogenic cycle and summer mortality phenomenon in the Pacific oyster (Crassostrea gigas) in Washington State. J Shellfish Res 1981; 1:916.

Pigeot J, Miramand P, Guyo T, Sauriau PG, Fichet D, Le Moine O, Huet V. Cadmium pathways in an exploited intertidal ecosystem with chronic cadmium inputs (Marennes-Oléron, Atlantic coast, France). Mar Ecol Prog Ser 2006; 307:101-114.

Porte C, Albaiges J. Bioaccumulation patterns of PCB congeners in bivalves, crustaceans and fishes from the Mediterranean coast. Implications in biomonitoring studies. Arch Envir Cont Toxicol 1993; 26:273-81.

Porte C, Biosca X, Pastor D, Sole M, Albaigés J. The Aegean Sea oil spill. 2. Temporal study of the hydrocarbons accumulation in bivalves. Environ Sci Technol 2000; 34:5067-75.

Readman JW, Fillmann G, Tolosa I, Bartocci J, Villeneuve JP, Catinni C, Mee LD. Petroleum and PAH contamination of the Black Sea. Mar Poll Bull 2002; 44:48-62.

Romeo M, Mourgaud Y, Geffard A, Gnassia-Barelli M, Amiard JC, Budzinski H. Multimarker approach in transplanted mussels for evaluating water quality in Charentes, France, coast areas exposed to different anthropogenic conditions. Environ Toxicol 2003; 18:295-305.

Ruiz Y, Suarez P, Alonso A, Longo E, Villaverde A, San Juan F. Environmental quality of mussel farms in the Vigo estuary: Pollution by PAHs, origin and effects on reproduction. Environ Poll 2011; 159:25065.

Sanchez J, Sole M, Albaiges J. A comparison of distribution of PCB congeners and other chlorinated compounds in fishes from coastal areas and remote lakes. Int J Environ Anal Chem 1993; 50:269-84.

Scanes PR. Uptake and depuration of organochlorine compounds in Sydney rock oysters (Saccostrea commercialis). Marine Freshwater Res 1997; 48:1-6.

Schmitt CJ, Zajicek JL, Peterman PH. National contaminant biomonitoring program: residues of organochlorine chemicals in U. S. Freshwater fish, 1974-1984. Arch Environ Contam Toxicol 1990; 19:748-81.

Soletchnik P, le Moine O, Faury N, Razet D, Geairon P, Goulletquer P. Mortalité de l'huître Crassostrea gigas dans le bassin de Marennes-Oléron: étude sur la variabilité spatiale de son environnement et de sa biologie par le système d'informations geographiques (SIG). Aquat Living Res 1999; 12:131-43.

Soriano JA, Viñas L, Franco MA, González JJ, Oriz L, Bayona JM, Albaigés J. Spatial and temporal trends of petroleum hydrocarbons in wild mussels from the Galician coast (NW Spain) affected by the Prestige oil spill. Sci Total Environ 2006; 370:80-90.

Tapie N, Budzinski H, Le Menach K. Fast and efficient extraction methods for the analysis of polychlorinated biphenyls and polybrominated diphenyl ethers in biological matrices. Anal Bioanal Chem 2008; 391:2169-77. 
Thompson S, Budzinski H, Garrigues P, Narbonne JF. Comparison of PCB and DDT distribution between water-column and sediment-dwelling bivalves in Arcachon Bay, France. Mar Poll Bull 1999; 38:65562.

Thompson S, Budzinski H. Determination of polychlorinated biphenyls and chlorinated pesticides in environmental biological samples using focused microwave-assisted extraction. Int J Envir Anal Chem 2000; 76:49-60.

Zar J. Biostatistical analysis. 2d ed. New Jersey: Prentice-Hall; 1984. 


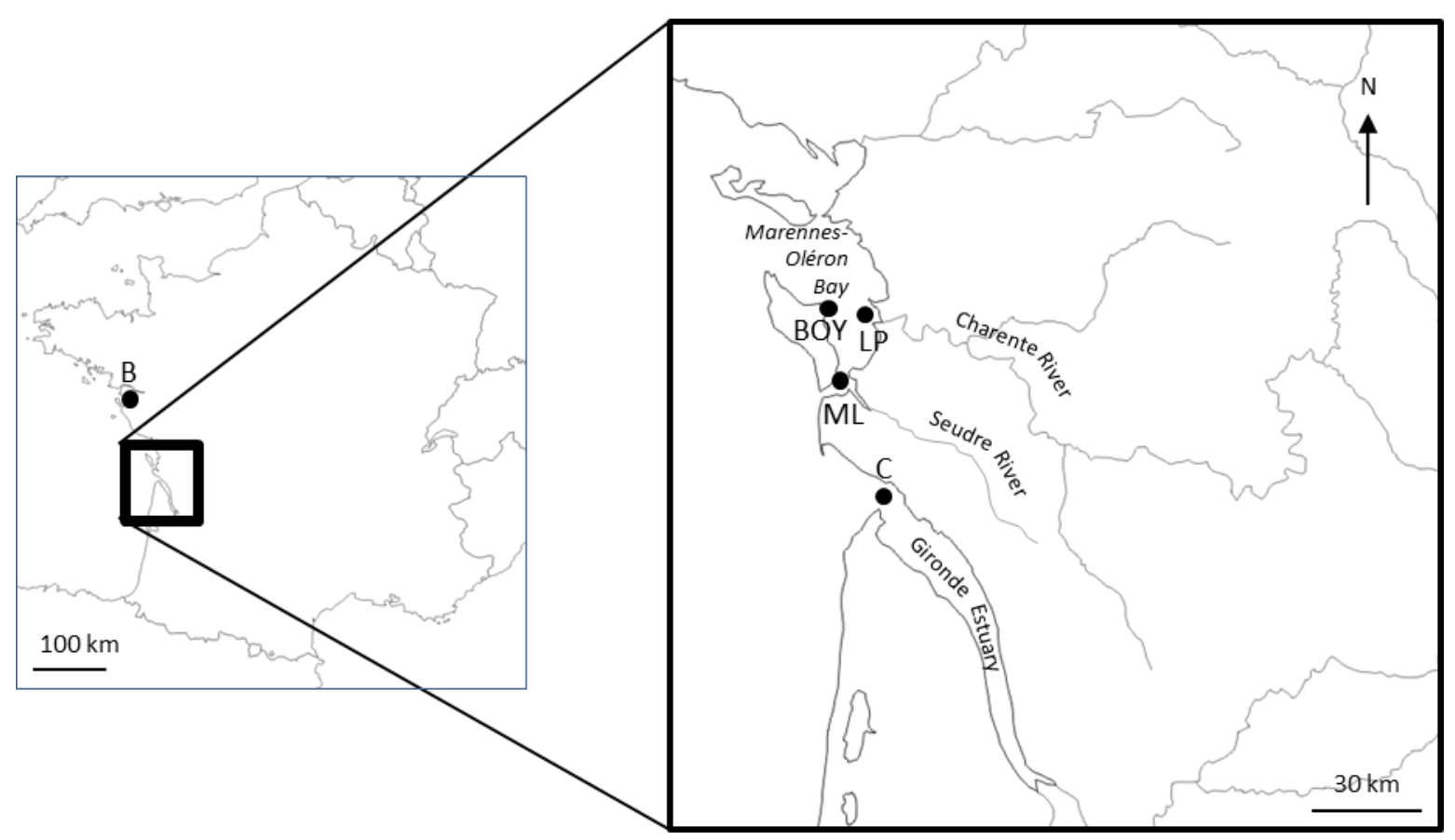

Figure 1. Estuarine sampling areas in French Atlantic coast (a) Location of reference (B, Bouin) and transplantation sites: Boyard (BOY), Les Palles (LP), Mus du Loup (ML) in the Marennes-Oléron Bay and Cordouan (C) in the Gironde Estuary. 


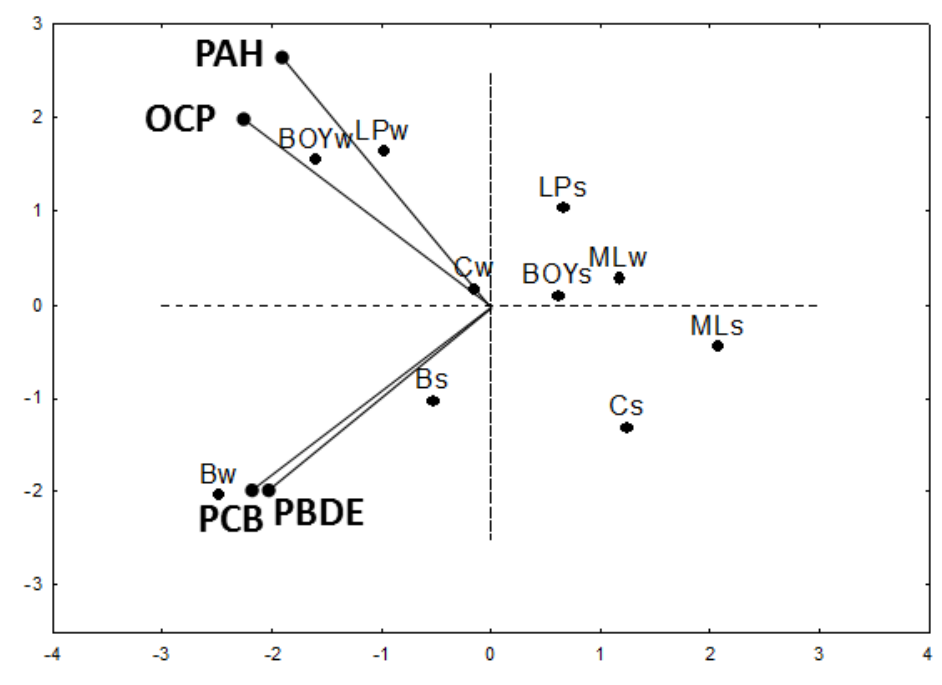

Figure 2. Principal component ordination of oyster tissue contaminant concentrations. (a) Projection of the variables on the factor-plane. (b) Projection of the sites on the factor-plane. PAH: polyaromatic hydrocarbons; PCB: polychlorobiphenyls; PBDE polybromodimethylethers; OCP: organochlorine pesticides; B: Bouin; BOY: Boyard; ML: Mus du Loup; LP: Les Palles; C: Cordouan; s: summer; w: winter. 


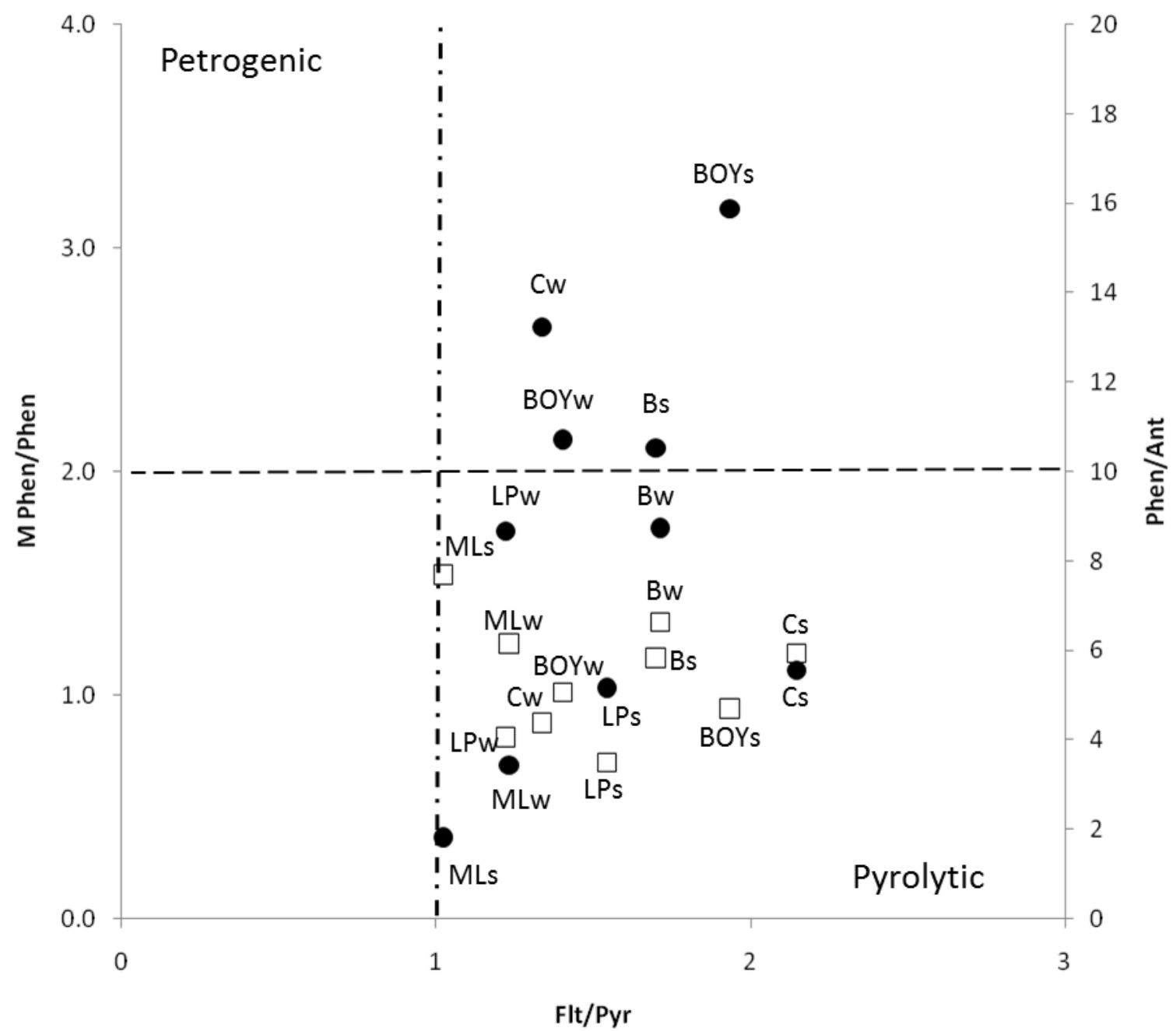

Figure 3. Chemical indices to discriminate petrogenic/pyrolytic aromatic hydrocarbons. Phen/Anth, phenanthrene/anthracene ratio, Flt/P, fluoranthene/pyrene ratio, MPhen/Phen methyl phenanthrene/phenanthrene ratio, B: Bouin; BOY: Boyard, LP: Les Palles, ML: Mus du Loup; C: Cordouan; s: summer; w: winter. MPhen/Phen in squares; Phen/Ant in circles. Continuous dotted line correspondss to the limit between petrogenic and pyrolytic sources according to the ratios MPhen/Phen and Phen/Ant; discontinuous dotted line corresponds to the limit between petrogenic and pyrolytic sources according to the ratio Flt/Pyr. 

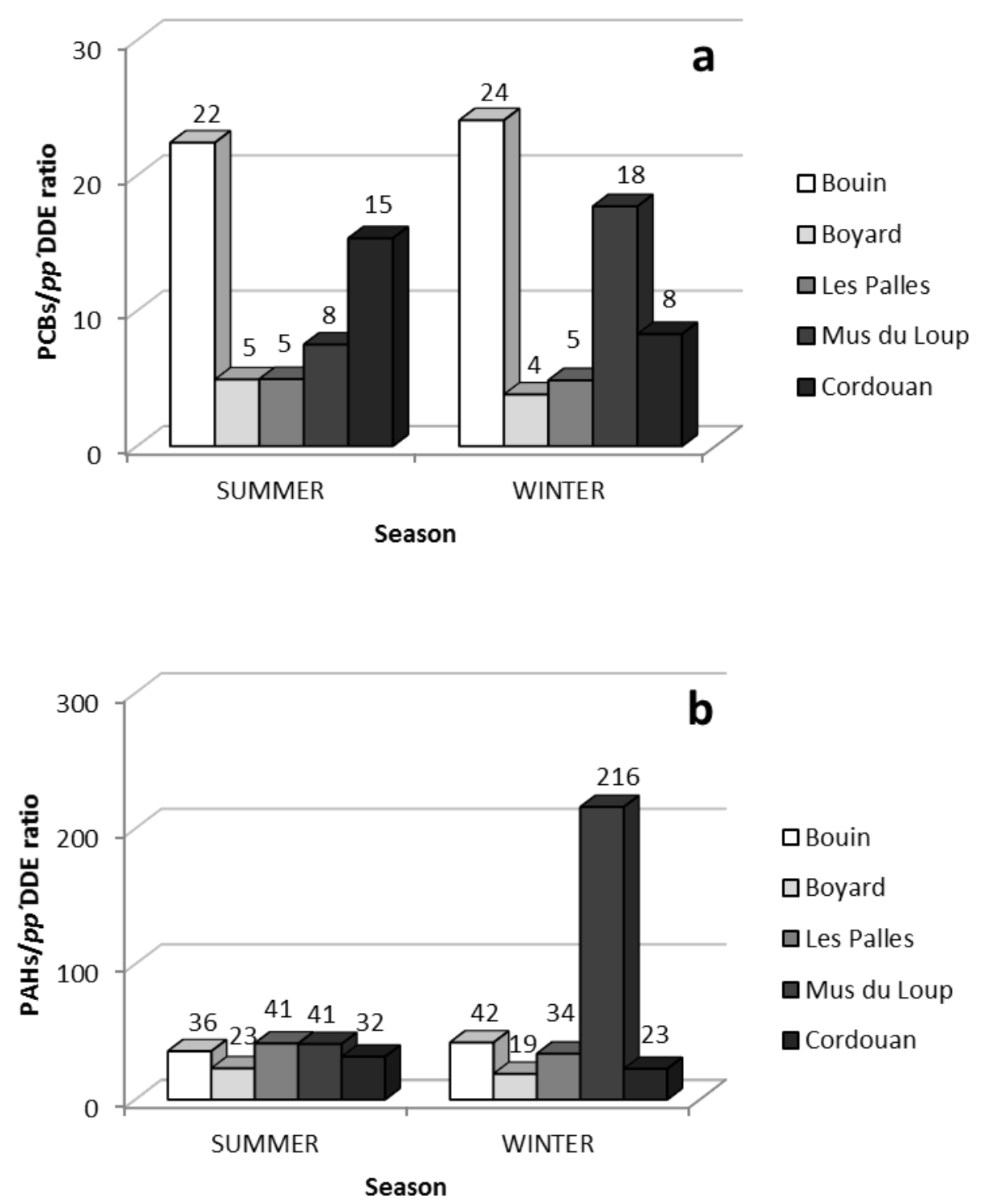

Figure 4. PCBs/pp DDE (a) and PAHs/pp DDE (b) ratios in the soft tissue of the Pacific oyster Crassostrea gigas from reference (Bouin) and transplantation sites, in the Marennes-Oléron Bay (Boyard, Les Palles, Mus du Loup) and in the Gironde Estuary (Cordouan). 


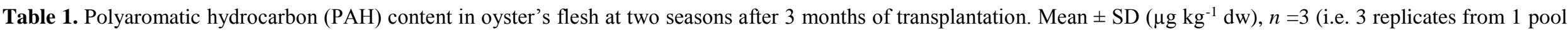

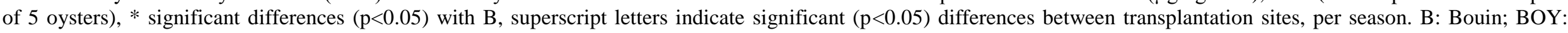
Boyard; LP: Les Palles; ML: Mus du Loup; C: Cordouan; dw: dry weight; nd: not detected.

\begin{tabular}{|c|c|c|c|c|c|c|c|c|c|c|c|c|}
\hline \multirow{3}{*}{ PAHs (parents and alkylated) } & \multirow{3}{*}{$\begin{array}{l}\text { No. of } \\
\text { aromatic rings }\end{array}$} & \multirow{3}{*}{$\begin{array}{l}\text { Molecular } \\
\text { weight }\left(\mathrm{g} \cdot \mathrm{mol}^{-1}\right)\end{array}$} & \multicolumn{10}{|c|}{ Concentration $\left(\mu \mathrm{g} . \mathrm{kg}^{-1} \mathbf{d w}\right)$} \\
\hline & & & \multicolumn{5}{|c|}{ Summer } & \multicolumn{5}{|l|}{ Winter } \\
\hline & & & B & BOY & LP & ML & $\mathbf{C}$ & B & BOY & LP & ML & $\mathbf{C}$ \\
\hline Naphthalene & 3 & 128 & $7.5 \pm 0.3$ & $4.9 \pm 1.4$ & $3.0 \pm 1.1$ & $4.8 \pm 0.2$ & $5.7 \pm 3.3$ & $2.9 \pm 0.9$ & $3.2 \pm 2.0$ & $3.8 \pm 1.5$ & $4.0 \pm 0.2$ & $3.2 \pm 0.6$ \\
\hline C1-Naphthalene & 3 & 143 & $4.2 \pm 0.5$ & $4.5 \pm 2.0$ & $3.8 \pm 2.5$ & $4.8 \pm 0.5$ & $5.1 \pm 2.6$ & $2.9 \pm 0.7$ & $4.9 \pm 2.7$ & $3.6 \pm 0.8$ & $3.0 \pm 0.7$ & $3.5 \pm 0.3$ \\
\hline C2-Naphthalene & 3 & 158 & $6.6 \pm 0.4$ & $8.1 \pm 4.4$ & $7.3 \pm 5.6$ & $8.7 \pm 0.7$ & $9.7 \pm 5.5$ & $5.2 \pm 0.9$ & $8.4 \pm 4.4$ & $7.2 \pm 1.7$ & $5.7 \pm 1.4$ & $6.5 \pm 0.5$ \\
\hline Acenaphtylene & 3 & 155 & nd & nd & nd & nd & nd & $0.5 \pm 0.1$ & $0.6 \pm 0.1$ & nd & $0.5 \pm 0.1$ & $0.5 \pm 0.1$ \\
\hline Acenaphtene & 3 & 154 & $3.3 \pm 0.0$ & $2.1 \pm 0.2$ & $2.3 \pm 0.1$ & $0.9 \pm 0.1$ & $1.6 \pm 0.3$ & $2.3 \pm 0.6$ & $3.3 \pm 1.3$ & $2.8 \pm 0.4$ & $4.5 \pm 0.2$ & $4.7 \pm 1.3$ \\
\hline Fluorene & 3 & 166 & $3.3 \pm 0.4$ & $2.9 \pm 0.2$ & $3.0 \pm 1.0$ & $0.5 \pm 0.1$ & $1.9 \pm 0.9$ & $2.5 \pm 0.8$ & $2.9 \pm 0.8$ & $1.6 \pm 1.0$ & $1.6 \pm 0.2$ & $2.2 \pm 0.7$ \\
\hline Phenanthrene & 3 & 178 & $19.6 \pm 0.8$ & $16.4 \pm 0.1$ & $12.5 \pm 1.5$ & $2.1 \pm 0.0$ & $8.0 \pm 5.5$ & $20.5 \pm 8.7$ & $21.4 \pm 4.8$ & $20.1 \pm 6.4$ & $8.2 \pm 3.2$ & $10.2 \pm 1.8$ \\
\hline C1-+C9-Phenanthrene+C1-Anthracene & 3 & $208-238$ & $7.1 \pm 0.4$ & $6.4 \pm 0.2$ & $4.7 \pm 1.7$ & $1.4 \pm 0.3$ & $3.5 \pm 3.8$ & $10.8 \pm 4.5$ & $7.8 \pm 1.1$ & $7.4 \pm 2.1$ & $4.4 \pm 0.8$ & $4.9 \pm 1.5$ \\
\hline C2-+C3-Phenanthrene & 3 & $223-238$ & $12.5 \pm 5.3$ & $8.2 \pm 1.4$ & $5.5 \pm 1.1$ & $1.8 \pm 0.1$ & $6.0 \pm 2.0$ & $16.5 \pm 10.0$ & $11.1 \pm 5.0$ & $8.9 \pm 2.2$ & $5.6 \pm 0.3$ & $5.4 \pm 1.1$ \\
\hline Anthracene & 3 & 178 & $1.9 \pm 0.1$ & $1.0 \pm 0.1$ & $2.4 \pm 0.3$ & $1.2 \pm 0.1$ & $1.4 \pm 0.7$ & $2.4 \pm 1.9$ & $2.0 \pm 1.0$ & $2.3 \pm 0.4$ & $2.4 \pm 0.1$ & $0.8 \pm 0.4$ \\
\hline C2-Anthracene & 3 & 193 & $0.6 \pm 0.2$ & $1.9 \pm 1.4$ & $1.5 \pm 0.6$ & $0.6 \pm 0.2$ & $1.0 \pm 0.4$ & nd & $0.9 \pm 0.0$ & $0.8 \pm 0.6$ & $0.4 \pm 0.0$ & $1.1 \pm 0.5$ \\
\hline Dibenzothiophene & 3 & 184 & $1.6 \pm 0.3$ & $1.0 \pm 0.2$ & $0.9 \pm 0.3$ & nd & $0.9 \pm 0.4$ & $2.2 \pm 0.7$ & $1.6 \pm 0.3$ & $0.8 \pm 0.8$ & $0.5 \pm 0.2$ & $0.5 \pm 0.1$ \\
\hline$\sum$ Light PAHs & & & $68 \pm 6$ & $58 \pm 9$ & $47 \pm 14$ & $27 \pm 1$ & $45 \pm 25$ & $69 \pm 16$ & $68 \pm 19$ & $60 \pm 12$ & $41 \pm 5$ & $44 \pm 5$ \\
\hline Fluoranthene & 4 & 202 & $7.9 \pm 0.3$ & $12.0 \pm 1.6$ & $21.4 \pm 0.3$ & $6.3 \pm 0.4$ & $6.1 \pm 2.6$ & $15.1 \pm 2.1$ & $33 \pm 5.9$ & $20.6 \pm 3$ & $21.3 \pm 4.7$ & $16.1 \pm 2.4$ \\
\hline Pyrene & 4 & 202 & $4.7 \pm 0.4$ & $6.2 \pm 0.5$ & $13.9 \pm 2$ & $6.1 \pm 0.5$ & $2.8 \pm 1.4$ & $8.8 \pm 0.8$ & $23.6 \pm 2.9$ & $16.9 \pm 1.2$ & $17.3 \pm 4.1$ & $12 \pm 1.6$ \\
\hline Benzo(a)anthracene & 4 & 228 & $2.2 \pm 0.6$ & $6.1 \pm 1.7$ & $10.2 \pm 4.1$ & $3.9 \pm 1.1$ & $2.9 \pm 0.9$ & $3.9 \pm 0.3$ & $13.9 \pm 2.2$ & $9.9 \pm 0.7$ & $9.2 \pm 4.3$ & $3.1 \pm 0.6$ \\
\hline Triphenylene+Chrysene & 4 & 228 & $4.2 \pm 0.4$ & $8.9 \pm 2.1$ & $13.1 \pm 3.5$ & $5.8 \pm 0.7$ & $3.4 \pm 1.1$ & $8.2 \pm 1.4$ & $21.1 \pm 0.6$ & $15.9 \pm 0.9$ & $18.9 \pm 1.3$ & $8.7 \pm 1.4$ \\
\hline Benzo(b)naptho(2,1-d)thiophene & 4 & 234 & $0.7 \pm 0.0$ & $1.3 \pm 0.1$ & $3.6 \pm 0.8$ & $0.9 \pm 0.2$ & $0.4 \pm 0.2$ & $1.1 \pm 0.7$ & $3.3 \pm 0.3$ & $3 \pm 0.7$ & $3.1 \pm 0.7$ & $1.2 \pm 0.2$ \\
\hline $\operatorname{Benzo}(b, k, j)$ fluoranthene & 5 & 252 & $15.7 \pm 0.8$ & $22.5 \pm 3.1$ & $36.6 \pm 4.4$ & $14.6 \pm 3.3$ & $6.8 \pm 1.4$ & $19.8 \pm 2.9$ & $21 \pm 19.7$ & $36 \pm 3.0$ & $39.5 \pm 2.9$ & $13.3 \pm 2.4$ \\
\hline Benzo(e)pyrene & 5 & 252 & $8.0 \pm 0.9$ & $10.9 \pm 1.6$ & $15.0 \pm 2.5$ & $6.5 \pm 1.5$ & $3.5 \pm 0.2$ & $8.4 \pm 1.5$ & $15.5 \pm 2.0$ & $13.8 \pm 2.0$ & $17.7 \pm 0.4$ & $7.8 \pm 1.7$ \\
\hline Benzo(a)pyrene & 5 & 252 & $2.4 \pm 0.4$ & $2.5 \pm 0.3$ & $5.0 \pm 1.6$ & $1.8 \pm 0.5$ & $1.3 \pm 0.6$ & $2.7 \pm 0.4$ & $9.5 \pm 3.0$ & $7.6 \pm 0.2$ & $7.0 \pm 5.3$ & $1.6 \pm 0.3$ \\
\hline Perylene & 5 & 252 & $6.9 \pm 1.1$ & $4.5 \pm 0.0$ & $6.3 \pm 0.2$ & $3.4 \pm 0.6$ & $5.3 \pm 0.7$ & $8.3 \pm 0.8$ & $5.5 \pm 0.3$ & $4.8 \pm 0.8$ & $4.6 \pm 2.0$ & $6.8 \pm 0.3$ \\
\hline Benzo(g,h,i)perylene & 5 & 276 & $4.3 \pm 0.4$ & $2.9 \pm 0.7$ & $5.6 \pm 1.2$ & $2.1 \pm 0.7$ & $1.1 \pm 0.1$ & $4.5 \pm 1.6$ & $9.1 \pm 0.5$ & $6.7 \pm 0.3$ & $8.9 \pm 3.7$ & $2.5 \pm 0.5$ \\
\hline Indeno(1,2,3-cd)pyrene & 5 & 276 & $2.8 \pm 0.2$ & $3.0 \pm 0.2$ & $8.2 \pm 2.0$ & $2.0 \pm 0.8$ & $1.3 \pm 0.5$ & $4.6 \pm 1.1$ & $10.1 \pm 0.7$ & $8.2 \pm 0.3$ & $9.6 \pm 4.8$ & $2.5 \pm 0.2$ \\
\hline Dibenzo(a,h)anthracene+dibenzo(a,c)anthracene & 5 & 278 & nd & $0.5 \pm 0.1$ & $2.6 \pm 1.0$ & $0.4 \pm 0.1$ & nd & $1.2 \pm 0.4$ & $1.8 \pm 0.1$ & $1.7 \pm 0.2$ & $2.4 \pm 1.0$ & $0.9 \pm 0.2$ \\
\hline$\sum$ Heavy PAHs & & & $60 \pm 1$ & $81 \pm 10$ & $141 \pm 11$ & $54 \pm 10$ & $35 \pm 7$ & $87 \pm 10$ & $167 \pm 25$ & $145 \pm 3$ & $159 \pm 34$ & $76 \pm 12$ \\
\hline$\sum$ Total PAHs & & & $129 \pm 6$ & $139 \pm 19^{\mathrm{a}, \mathrm{b}}$ & $189 \pm 25^{a}$ & $81 \pm 11^{b}$ & $80 \pm 32^{a, b}$ & $155 \pm 25$ & $236 \pm 43^{*},{ }^{a}$ & $205 \pm 9^{a}$ & $200 \pm 40^{\mathrm{a}}$ & $120 \pm 16^{b}$ \\
\hline
\end{tabular}


Table 2. Polychlorobiphenyl (PCB) and polybromodimethylether (PBDE) contents in oyster's flesh at two seasons after 3 months of transplantation. Mean \pm SD ( $\mu \mathrm{g}$ kg ${ }^{-1} \mathrm{dw}$ ), $n$ $=3$ (i.e. 3 replicates from 1 pool of 5 oysters), * significant differences $(\mathrm{p}<0.05)$ with $\mathrm{B},{ }^{+}$significant differences $(\mathrm{p}<0.05)$ between $\mathrm{B}$ samples from summer and winter. B: Bouin; BOY: Boyard; LP: Les Palles; ML: Mus du Loup; C: Cordouan; dw: dry weight; nd: not detected.

\begin{tabular}{|c|c|c|c|c|c|c|c|c|c|c|c|c|c|}
\hline \multirow{3}{*}{ Congeners } & & \multirow{3}{*}{$\begin{array}{l}\text { No. of chlorine or } \\
\text { bromine atoms }\end{array}$} & \multirow{3}{*}{$\begin{array}{l}\text { Molecular } \\
\text { weight }\left(\mathrm{g} \mathrm{mol}^{-1}\right)\end{array}$} & \multicolumn{10}{|c|}{ Concentration $\left(\mu \mathrm{g} \mathrm{kg}^{-1} \mathrm{dw}\right)$} \\
\hline & & & & \multicolumn{5}{|l|}{ Summer } & \multicolumn{5}{|l|}{ Winter } \\
\hline & & & & $\mathbf{B}$ & BOY & LP & ML & $\mathbf{C}$ & $\mathbf{B}$ & BOY & LP & ML & $\mathbf{C}$ \\
\hline \multirow{7}{*}{ PCB } & CB $50+28$ & 4 & $292-256$ & $1.3 \pm 0.2$ & $0.6 \pm 0.2$ & $0.4 \pm 0.1$ & $1.0 \pm 0.6$ & $1.3 \pm 0.8$ & $2.9 \pm 1.8$ & $0.5 \pm 0.3$ & $0.5 \pm 0.2$ & $0.5 \pm 0.1$ & $0.7 \pm 0.2$ \\
\hline & CB 52 & 4 & 292 & $16.7 \pm 1.5$ & $3.1 \pm 1.2$ & $1.8 \pm 0.2$ & $1.2 \pm 0.6$ & $3.3 \pm 2.5$ & $14.4 \pm 7.6$ & $4.9 \pm 3.0$ & $3.3 \pm 0.2$ & $0.4 \pm 0.0$ & $2.7 \pm 2.5$ \\
\hline & CB 101 & 5 & 326 & $14 \pm 0.5$ & $3.6 \pm 1.8$ & $1.4 \pm 0.5$ & $0.9 \pm 0.0$ & $4.0 \pm 1.7$ & $17.2 \pm 8.7$ & $5.1 \pm 3.1$ & $1.2 \pm 0.0$ & $2.6 \pm 0.8$ & $3.4 \pm 0.8$ \\
\hline & CB 118 & 5 & 326 & $15.7 \pm 3.1$ & $5.8 \pm 2.2$ & $4.3 \pm 0.9$ & $2.3 \pm 0.2$ & $5.2 \pm 3.6$ & $20.2 \pm 11.1$ & $11.5 \pm 3.5$ & $8.1 \pm 5.0$ & $2.1 \pm 1.2$ & $4.3 \pm 0.7$ \\
\hline & CB 138 & 6 & 361 & $12.9 \pm 1.8$ & $6 \pm 0.6$ & $4.0 \pm 0.9$ & $2.4 \pm 0.1$ & $7.3 \pm 2.8$ & $11.1 \pm 2.5$ & $8.8 \pm 3.0$ & $4.7 \pm 0.1$ & $3.1 \pm 2.5$ & $8.3 \pm 1.7$ \\
\hline & CB 153 & 6 & 361 & $17.8 \pm 2.3$ & $9.7 \pm 2.3$ & $9.2 \pm 2.2$ & $6.4 \pm 0.4$ & $15.4 \pm 1.7$ & $19.3 \pm 6.2$ & $15.3 \pm 7.2$ & $11.5 \pm 1.8$ & $6.8 \pm 1.4$ & $21.7 \pm 6.7$ \\
\hline & CB 180 & 7 & 395 & $2.3 \pm 0.1$ & $1 \pm 0.4$ & $1.5 \pm 0.5$ & $0.5 \pm 0.1$ & $2.4 \pm 0.5$ & $3.6 \pm 1.1$ & $1.3 \pm 0.2$ & $0.8 \pm 0.2$ & $1.1 \pm 0.1$ & $2.6 \pm 0.2$ \\
\hline$\Sigma$ PCBs & & & & $81 \pm 9$ & $30 \pm 3^{*}$ & $23 \pm 4 *$ & $15 \pm 1 *$ & $39 \pm 12 *$ & $89 \pm 39$ & $47 \pm 3 *$ & $30 \pm 3^{*}$ & $17 \pm 6^{*}$ & $44 \pm 4 *$ \\
\hline \multirow{4}{*}{ PBDE } & BDE 47 & 4 & 486 & $0.9 \pm 0.0$ & $0.4 \pm 0.3$ & $0.4 \pm 0.3$ & $0.4 \pm 0.0$ & $0.9 \pm 0.2$ & $1.5 \pm 0.4$ & $0.5 \pm 0.3$ & $0.5 \pm 0.3$ & $0.6 \pm 0.1$ & $0.5 \pm 0.1$ \\
\hline & BDE 99 & 5 & 565 & nd & $0.2 \pm 0.0$ & nd & nd & nd & $1.5 \pm 0.4$ & $0.4 \pm 0.0$ & $0.9 \pm 0.0$ & nd & nd \\
\hline & BDE 119 & 5 & 565 & nd & nd & nd & nd & nd & nd & nd & nd & nd & nd \\
\hline & BDE 153 & 6 & 644 & nd & nd & nd & nd & nd & nd & nd & nd & nd & nd \\
\hline$\Sigma$ PBDEs & & & & $0.9 \pm 0.0$ & $0.4 \pm 0.4$ & $0.4 \pm 0.3$ & $0.4 \pm 0.0$ & $0.9 \pm 0.2$ & $2.9 \pm 0.7^{\dagger}$ & $0.6 \pm 0.3 *$ & $1.0 \pm 0.7 *$ & $0.6 \pm 0.1 *$ & $0.5 \pm 0.1 *$ \\
\hline
\end{tabular}


Table 3. Organochlorine pesticide (OCP) content in oyster's flesh at two seasons after 3 months of transplantation. Mean $\pm \mathrm{SD}\left(\mu \mathrm{g} \mathrm{kg}{ }^{-1} \mathrm{dw}\right), n=3$ (i.e. 3 replicates from 1 pool of 5 oysters), * significant differences $(\mathrm{p}<0.05)$ with $\mathrm{B}$, superscript letters indicate significant $(\mathrm{p}<0.05)$ differences between transplantation sites, per season. B: Bouin; BOY: Boyard; LP: Les Palles; ML: Mus du Loup; C: Cordouan; dw: dry weight; HCB: hexachlorobenzene; DDT: dichlorodiphenyltrichloroethane; DDE: dichlorodiphenyldichloroethylene; DDD: dichlorodiphenyldichloroethane; CB: chlorobiphenyl; nd: not detected.

\begin{tabular}{|c|c|c|c|c|c|c|c|c|c|c|c|c|}
\hline \multirow{3}{*}{ OCP (common name) } & \multirow{3}{*}{$\begin{array}{l}\text { No. of } \\
\text { chlorine } \\
\text { atoms }\end{array}$} & \multirow{3}{*}{$\begin{array}{l}\text { Molecular } \\
\text { weight }(\mathrm{g} \\
\left.\text { mol }^{-1}\right)\end{array}$} & \multicolumn{10}{|c|}{ Concentration $\left(\mu \mathrm{g} \mathrm{kg}^{-1} \mathrm{dw}\right)$} \\
\hline & & & \multicolumn{5}{|l|}{ Summer } & \multicolumn{5}{|l|}{ Winter } \\
\hline & & & B & BOY & $\mathbf{L P}$ & ML & $\mathbf{C}$ & $\mathbf{B}$ & BOY & $\mathbf{L P}$ & ML & $\mathbf{C}$ \\
\hline $\mathrm{HCB}$ & 6 & 285 & $1.4 \pm 0.5$ & $1.6 \pm 1.0$ & $1.4 \pm 0.3$ & $0.4 \pm 0.0$ & $0.4 \pm 0.0$ & $1.2 \pm 0.6$ & $1.9 \pm 0.2$ & $2.2 \pm 0.8$ & nd & $0.6 \pm 0.1$ \\
\hline Lindane & 6 & 291 & $2.1 \pm 0.4$ & $0.6 \pm 0.1$ & $0.4 \pm 0.0$ & nd & nd & $2.2 \pm 1.1$ & $0.5 \pm 0.2$ & $1.3 \pm 0.3$ & $0.6 \pm 0.0$ & $0.7 \pm 0.4$ \\
\hline 2,4'DDE & 4 & 318 & $2.2 \pm 1.0$ & $2.4 \pm 1.0$ & $1.5 \pm 0.2$ & nd & $0.3 \pm 0.0$ & $2.5 \pm 1.4$ & $5.5 \pm 2.9$ & $2.4 \pm 1.2$ & nd & nd \\
\hline 4,4'DDE + Dieldrin & $4-6$ & $318-381$ & $1.4 \pm 0.2$ & $3.6 \pm 1.3$ & $2.4 \pm 0.3$ & $0.9 \pm 0.1$ & $1.9 \pm 0.1$ & $1.2 \pm 0.2$ & $6.8 \pm 2.3$ & $3.7 \pm 0.9$ & $0.8 \pm 0.1$ & $3.0 \pm 1.6$ \\
\hline 2,4'DDD + (CB154+77) & $4-6-4$ & $320-361-295$ & nd & nd & nd & nd & nd & nd & nd & nd & nd & nd \\
\hline 4,4'DDD & 4 & 320 & $2.3 \pm 0.0$ & $1.9 \pm 0.3$ & $2.0 \pm 0.1$ & $1.0 \pm 0.0$ & $1.1 \pm 0.1$ & $1.5 \pm 0.6$ & $2.8 \pm 0.4$ & $3.7 \pm 0.8$ & $1.9 \pm 0.1$ & $3.9 \pm 0.4$ \\
\hline $2,4^{\prime} \mathrm{DDT}$ & 5 & 355 & $0.4 \pm 0.1$ & nd & nd & nd & nd & $0.9 \pm 0.6$ & nd & nd & $0.8 \pm 0.1$ & $1.2 \pm 0.2$ \\
\hline $4,4^{\prime} \mathrm{DDT}$ & 5 & 355 & nd & nd & nd & nd & nd & nd & nd & nd & nd & nd \\
\hline Heptachlor & 7 & 373 & $0.3 \pm 0.0$ & $0.8 \pm 0.5$ & $0.6 \pm 0.0$ & nd & nd & nd & $1.6 \pm 0.7$ & $1.9 \pm 1.0$ & $0.5 \pm 0.0$ & $0.7 \pm 0.3$ \\
\hline Heptachlor hepoxide & 7 & 373 & nd & nd & nd & nd & nd & nd & nd & nd & nd & nd \\
\hline Cis-chlordane & 8 & 410 & nd & nd & nd & nd & nd & nd & nd & nd & nd & nd \\
\hline Trans-nonachlor & 9 & 444 & $0.6 \pm 0.1$ & nd & nd & nd & $0.4 \pm 0.0$ & nd & nd & nd & $\mathrm{Nd}$ & $0.7 \pm 0.3$ \\
\hline Mirex + CB170 & $12-7$ & $546-395$ & nd & nd & nd & nd & nd & nd & nd & nd & nd & nd \\
\hline$\Sigma O C P s$ & & & $11 \pm 2$ & $11 \pm 1^{a}$ & $8 \pm 0^{\mathrm{a}, \mathrm{b}}$ & $3 \pm 0^{*, \mathrm{~b}}$ & $4 \pm 0^{*, \mathrm{~b}}$ & $10 \pm 5$ & $19 \pm 1^{*, a}$ & $15 \pm 3^{\mathrm{a}, \mathrm{c}}$ & $5 \pm 0^{b, c}$ & $11 \pm 1^{\mathrm{c}}$ \\
\hline
\end{tabular}


Table 4. Sum of polyaromatic hydrocarbons ( $\Sigma \mathrm{PAHs}$ ), sum of polychlorobiphenyles ( $\Sigma \mathrm{PCBs}$ ), sum of polybromodimethylethers ( $\Sigma \mathrm{PBDEs}$ ), and sum of organochlorine pesticides $(\Sigma \mathrm{OCPs})$ content in oyster's flesh at two seasons after 3 months of transplantation. Mean $\pm \mathrm{SD}\left(\mu \mathrm{g} \mathrm{kg}{ }^{-1} \mathrm{dw}\right), n=3$ (i.e. 3 replicates from 1 pool of 5 oysters), * significant differences $(p<0.05)$ with $B$, superscript letters indicate significant $(p<0.05)$ differences between transplantation sites, per season, ${ }^{+}$significant differences $(p<0.05)$ between $B$ samples from summer and winter. B: Bouin; BOY: Boyard; LP: Les Palles; ML: Mus du Loup; C: Cordouan; dw: dry weight; nd: not detected.

Concentration $\left(\mu \mathrm{g} \mathrm{kg}^{-1} \mathrm{dw}\right)$

\begin{tabular}{|c|c|c|c|c|c|c|c|c|c|c|}
\hline \multirow{3}{*}{ Contaminants } & \multirow{2}{*}{\multicolumn{5}{|c|}{ Summer }} & \multirow{2}{*}{\multicolumn{5}{|c|}{ Winter }} \\
\hline & & & & & & & & & & \\
\hline & B & BOY & $\mathbf{L P}$ & ML & $\mathbf{C}$ & B & BOY & $\mathbf{L P}$ & ML & $\mathbf{C}$ \\
\hline$\sum$ PAHs & $129 \pm 6$ & $139 \pm 19^{a, b}$ & $189 \pm 25^{a}$ & $81 \pm 11^{\text {b }}$ & $80 \pm 32^{\mathrm{a}, \mathrm{b}}$ & $155 \pm 25$ & $236 \pm 43^{*}, \mathrm{a}$ & $205 \pm 9^{\mathrm{a}}$ & $200 \pm 40^{\mathrm{a}}$ & $120 \pm 16^{b}$ \\
\hline$\sum$ PCBs & $81 \pm 9$ & $30 \pm 3^{*}$ & $23 \pm 4 *$ & $15 \pm 1 *$ & $39 \pm 12 *$ & $89 \pm 39$ & $47 \pm 3^{*}$ & $30 \pm 3^{*}$ & $17 \pm 6^{*}$ & $44 \pm 4 *$ \\
\hline$\sum$ PBDEs & $0.9 \pm 0.0$ & $0.4 \pm 0.4$ & $0.4 \pm 0.3$ & $0.4 \pm 0.0$ & $0.9 \pm 0.2$ & $2.9 \pm 0.7^{+}$ & $0.6 \pm 0.3 *$ & $1.0 \pm 0.7 *$ & $0.6 \pm 0.1 *$ & $0.5 \pm 0.1 *$ \\
\hline$\sum$ OCPs & $11 \pm 2$ & $11 \pm 1^{a}$ & $8 \pm 0^{a, b}$ & $3 \pm 0 \%, b$ & $4 \pm 0 \%, b$ & $10 \pm 5$ & $19 \pm 1^{*, a}$ & $15 \pm 3^{\mathrm{a}, \mathrm{c}}$ & $5 \pm 0^{\mathrm{b}, \mathrm{c}}$ & $11 \pm 1^{\mathrm{c}}$ \\
\hline
\end{tabular}


Table 5. Physico-chemical and biological parameters of the reference (Bouin, B) and the transplantion sites (Boyard, BOY; Les Palles, LP; Mus du Loup, ML; Cordouan: C) in summer (June) and winter (December), 2008.

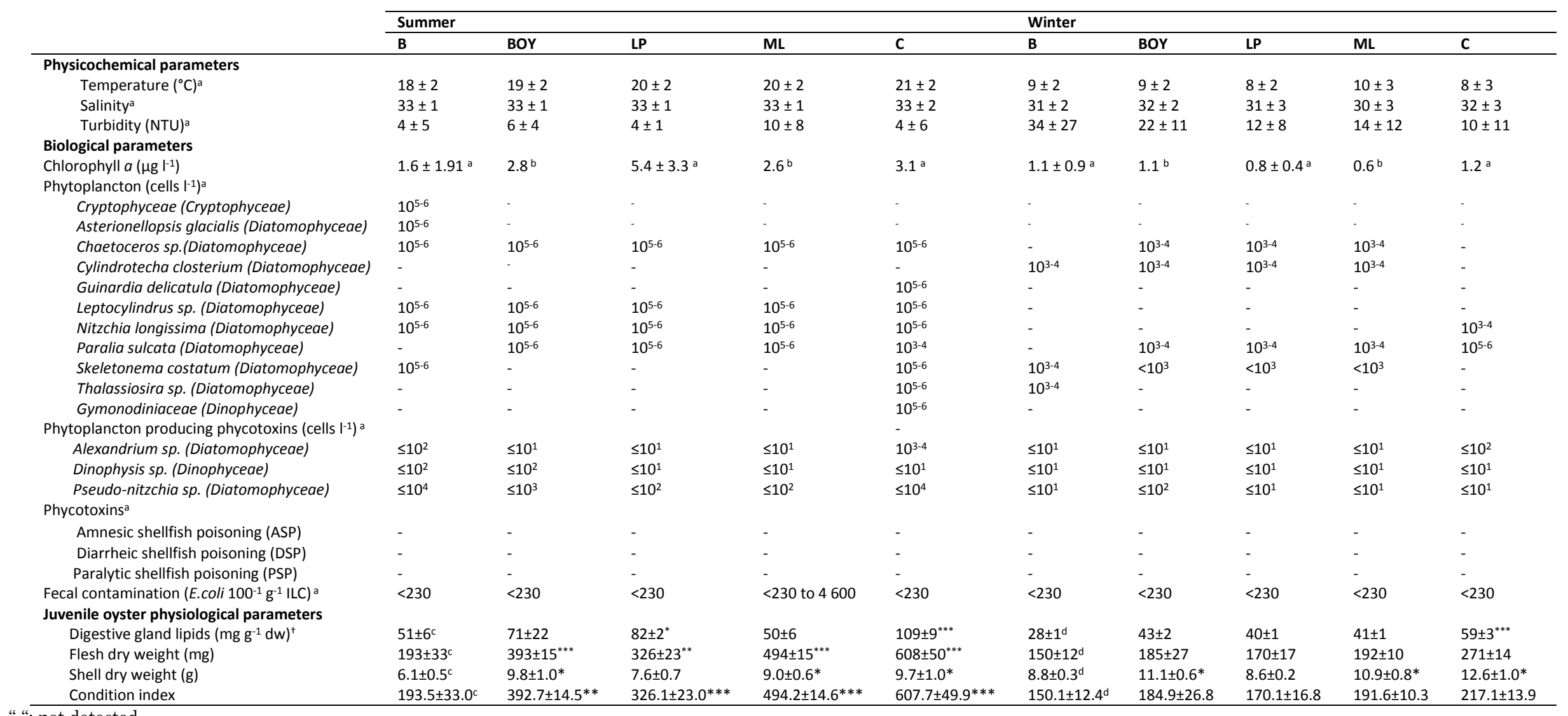

ILC: intervalvular liquid content

a Mean values \pm SD adapted from 2000 to 2006 data of the website "Site Ifremer consacré à l'environnement littoral": http://www.ifremer.fr/envlit/.

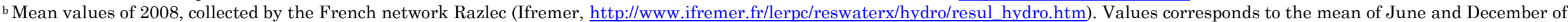
2008 of two measurements carried out per month at the bottom and at the top of the water surface from ML and sites near BOY and LP.

$* \mathrm{p}<0.05, * *<\mathrm{p} 0.01, * * * \mathrm{p}<0.001$

c, d Significant $(\mathrm{p}<0.05)$ differences between B samples from summer and winter.

${ }^{+}$Methodology for the obtention of data for this parameter is described in Luna-Acosta et al., submitted for this volume. 
Table 6. Contaminant contents in oysters reported by ROCCH (Réseau d'Observation de la Contamination Chimique du littoral) in the reference site (Bouin, B) and the transplanted sites (Boyard, BOY; Les Palles; LP, Mus du Loup, ML; Cordouan, C), from 2003 to 2007, and data collected in the present study in summer and winter in 2008.

\begin{tabular}{|c|c|c|c|c|c|c|c|}
\hline \multirow{2}{*}{ Contaminant contents } & & \multirow{2}{*}{ Data from } & \multicolumn{5}{|l|}{ Sites } \\
\hline & & & B & BOY & $\mathbf{L P}$ & ML & $\mathbf{C}$ \\
\hline \multirow{3}{*}{ PAHs $\left(\mu \mathrm{g} \mathrm{kg}^{-1} \mathrm{dw}\right)$} & \multirow{3}{*}{ Fluoranthene } & ROCCH 2003-2007a & 20 & 28 & 24 & 34 & 23 \\
\hline & & Summer 2008 & $8 \pm 0$ & $12 \pm 2$ & $21 \pm 0$ & $6 \pm 0$ & $6 \pm 3$ \\
\hline & & Winter 2008 & $15 \pm 2$ & $33 \pm 6$ & $4 \pm 2$ & $4 \pm 0$ & $3 \pm 1$ \\
\hline \multirow{3}{*}{ PCBs $\left(\mu \mathrm{g} \mathrm{kg}^{-1} \mathrm{dw}\right)$} & \multirow{3}{*}{ PCB153 } & ROCCH 2003-2007 & 37 & 16 & 17 & 16 & 65 \\
\hline & & Summer 2008 & $18 \pm 2$ & $10 \pm 2$ & $9 \pm 2$ & $6 \pm 0$ & $15 \pm 2$ \\
\hline & & Winter 2008 & $19 \pm 6$ & $15 \pm 7$ & $12 \pm 2$ & $7 \pm 1$ & $22 \pm 7$ \\
\hline \multirow{6}{*}{ Pesticides $\left(\mu \mathrm{g} \mathrm{kg}^{-1} \mathrm{dw}\right)$} & \multirow{3}{*}{$\begin{array}{l}\text { DDT, } \\
\text { metabolites }\end{array}$} & ROCCH 2003-2007 & 6 & 4 & 5 & 8 & 17 \\
\hline & & Summer 2008 & $6 \pm 1$ & $8 \pm 1$ & $7 \pm 1$ & $4 \pm 3$ & $4 \pm 1$ \\
\hline & & Winter 2008 & $6 \pm 3$ & $12 \pm 5$ & $10 \pm 1$ & $6 \pm 3$ & $10 \pm 3$ \\
\hline & \multirow{3}{*}{ Lindane } & ROCCH 2003-2007 & 0.4 & 0.8 & 0.5 & 0.9 & 0.4 \\
\hline & & Summer 2008 & $2.1 \pm 0.4$ & $0.6 \pm 0.1$ & $0.4 \pm 00$ & $0.1 \pm 0.1$ & $0.1 \pm 0.0$ \\
\hline & & Winter 2008 & $2.2 \pm 1.1$ & $0.5 \pm 0.2$ & $1.3 \pm 0.3$ & $0.6 \pm 0$ & $0.7 \pm 0.4$ \\
\hline
\end{tabular}

a Mean values collected from 2003 to 2007 data, at the website "Site Ifremer consacré à l'environnement littoral": $\underline{\text { http://www.ifremer.fr/envlit/. }}$ 